\title{
Fructo-oligosaccharides, hydrolyzed soy protein and yeast (Saccharomyces sp.) extract as potential cryoprotectans in gluten-free frozen dough and bread quality.
}

Fruto-oligossacarídeos, proteína hidrolisada de soja e extrato de levedura (Saccharomyces sp.) como potencial crioprotetor em massa congelada e qualidade de pães sem glúten.

Fructooligosacáridos, proteína de soja hidrolizada y extracto de levadura (Saccharomyces sp.) como potenciales crioprotectores en masa congelada y en la calidad de pan sin gluten.

Daniela de Oliveira Teotônio
ORCID: https://orcid.org/0000-00001-6734-4754
E-mail: teotonio.daniela@yahoo.com
Bederal University of Jequitinhonha and Mucurialleys, Arazil
ORCID: https://orcid.org/0000-0003-0510-7934
Federal University of Lavras, Brazil
E-mail: barbaraalana.costa@gmail.com
Paula Thamara Goecking Gomes
ORCID: https://orcid.org/0000-0003-4950-2397
E-mail: paulatgoecking@gmai.com
Mariana Pereira Santos
Federal University of Jequitinhonha and Mucuri Valleys, Brazil
Federal University of Jequitinhonha and Mucuri Valleys, Brazil
E-mail: maripdiamantina@gmail.com
Erick Flávio Guimarães Amaral
ORCID: https://orcid.org/0000-0002-8059-6478
Federal University of Minas Gerais, Brazil
E-mail: erickfa@live.com
Maria Teresa Pedrosa Silva Clerici
ORCID: https://orcid.org/0000-0002-8445-336X
University of Campinas, Brazil
E-mail: mclerici@unicamp.br
Maria Gabriela Vernaza Leoro
Federal University of Jequitinhonha and Mucuri Valleys, Brazil
E-mail: marcio.sc@ict.ufvjm.edu.br

\begin{abstract}
People with celiac disease, wheat allergy, and non-celiac gluten sensitivity required bakery products without gluten. However, gluten-free bread has a high rate of starch retrogradation during shelf life, resulting in loss of softness in the bread crumbs. The inclusion of frozen doughs for gluten-free bread can provide a feasible solution to increase product supply with high technological and sensory quality, providing fresh bread with uniform characteristics. The biggest challenge in the frozen dough for gluten-free bread is related to the high amount of water added to the dough (70-120 $\%$ - flour basis) because the ice crystals formed during the freezing step can cause damage to yeast. The use of cryoprotectants in the dough is an alternative for preserving yeast during freezing and cold chain maintenance. This study aimed to evaluate the behavior of fructo-oligosaccharide, hydrolyzed soy protein, and yeast extract as a cryoprotectant in the gluten-free frozen dough and the evaluation of bread quality. Through the Response Surface Methodology, using a Simplex-Centroid Mixture Design, the cryoprotectants were evaluated up to a concentration of 5 $\%$ (flour basis) with freezing of the dough for 7 days at $-18{ }^{\circ} \mathrm{C}$. The results showed that with the use of cryoprotectants, there was an increase in volume increase of the doughs, in the specific volume of the bread, and the softness of the crumb. The use of $69 \%$ fructo-oligosaccharide and $31 \%$ hydrolyzed soy protein, without the yeast extract, was considered as the optimal formulation for the tested cryoprotectants, with a probability of $79.60 \%$ of success obtained
\end{abstract}


by the desirability function. These levels promoted a better biopreservation of yeast fermentation power and resulting in an improved crumb softness and specific volume at 46 and $40 \%$, respectively, compared to the standard sample.

Keywords: Breadmaking; Yeast; Fermentation; Texture; Desirability; Celiac disease.

\section{Resumo}

Portadores de doença celíaca, alergia ao trigo e sensibilidade ao glúten não celíaca requerem produtos de panificação sem glúten. No entanto, o pão sem glúten tem uma alta taxa de retrogradação do amido durante a vida de prateleira, resultando na perda de maciez do miolo do pão. A inclusão de massas congeladas para pães sem glúten pode ser uma solução viável objetivando aumentar a oferta de produtos com alta qualidade tecnológica e sensorial, proporcionando pães frescos e com características uniformes. O maior desafio na produção de massa congelada para pão sem glúten está relacionado à grande quantidade de água adicionada à massa (70-120 \% - base farinha), pois os cristais de gelo formados durante a etapa de congelamento podem causar danos ao fermento. O uso de crioprotetores na massa é uma alternativa para conservar o fermento durante o congelamento e a manutenção da rede de frio. Este trabalho teve como objetivo avaliar o comportamento dos fruto-oligossacarídeos, da proteína hidrolisada de soja e do extrato de levedura como crioprotetor na massa congelada sem glúten e avaliar a qualidade do pão. Através da Metodologia de Superfície de Resposta, utilizando um Planejamento de Mistura Simplex-Centróide, os crioprotetores foram avaliados até a concentração de $5 \%$ (base farinha) e com o congelamento da massa por 7 dias a $-18{ }^{\circ} \mathrm{C}$. Os resultados mostraram que com o uso dos crioprotetores houve uma melhor nas características da massa, no volume de expansão das massas, no volume específico do pão e na maciez do miolo. O uso de $69 \%$ de fruto-oligossacarídeo e $31 \%$ de proteína de soja hidrolisada, sem o extrato de levedura, foi considerado a formulação ideal para os crioprotetores testados, com probabilidade de 79,60 \% de sucesso obtido pela função desejabilidade. Esses níveis promoveram uma melhor biopreservação do poder fermentativo das leveduras e resultaram em uma melhor maciez do miolo e volume específico de 46 e $40 \%$, respectivamente, em comparação com a amostra padrão.

Palavras-chave: Panificação; Levedura; Fermentação; Textura; Desejabilidade; Doença celíaca.

\section{Resumen}

Las personas con enfermedad celíaca, alergia al trigo y sensibilidad no celíaca al gluten necesitan productos de panadería sin gluten. Sin embargo, el pan sin gluten presenta una alta tasa de retrogradación del almidón durante la vida útil, lo que resulta en una pérdida de suavidad en el pan cortado. La inclusión de masas congeladas en el mercado de pan sin gluten puede proporcionar una solución viable para incrementar la oferta de productos con alta calidad tecnológica y sensorial, proporcionando pan fresco con características uniformes. El mayor desafío en la masa congelada en el pan sin gluten está relacionado con la gran cantidad de agua agregada a la masa (70-120 \% - base de harina) porque los cristales de hielo formados durante el proceso de congelación pueden dañar la levadura. El uso de crioprotectores en la masa es una alternativa para conservar la levadura durante la congelación así como el mantenimiento de la cadena de frío. Este estudio tuvo como objetivo evaluar el comportamiento de la adición de fructooligosacáridos, proteína de soja hidrolizada y extracto de levadura como crioprotectores en masa congelada y en la calidad del pan sin gluten. Mediante la Metodología de Superficie de Respuesta, utilizando un Diseño de Mezcla Simplex-Centroide, se evaluaron los crioprotectores hasta una concentración del $5 \%$ (base harina) con congelación de la masa durante 7 días a $-18{ }^{\circ} \mathrm{C}$. Los resultados mostraron que con el uso de crioprotectores, aumentaron el volumen de las masas, el volumen específico del pan y la suavidad de la miga. El uso de un $69 \%$ de fructooligosacáridos y un 31\% de proteína de soja hidrolizada, sin el extracto de levadura, se consideró como la formulación óptima para los crioprotectores estudiados, con una probabilidad de éxito del 79,60 \% obtenida por la función de deseabilidad. Estos niveles mostraron una mejor biopreservación del poder de fermentación de la levadura y dieron como resultado mayor suavidad de la miga y volumen específico de 46 y $40 \%$, respectivamente, en comparación con la muestra estándar.

Palabras clave: Panificación; Levadura; Fermetación; Textura; Deseabilidad; Enfermedad celíaca.

\section{Introduction}

The term "gluten intolerance" includes three classes of different disorders: (i) autoimmune, represented by celiac disease (CD); (ii) allergic, represented by wheat allergy (WA); and (iii) non-autoimmune and non-allergic, represented by non-celiac gluten sensitivity (NCGS) (Cabanillas, 2019; Roszkowska, Pawlick, Mroczek, Balabuszek \& Neradko-Iwanicka, 2019; Scherf, 2019; Arslain., Gustafson, Baishya \& Rose, 2021; Catassi, Naspi \& Catassi, 2021). Individuals who have some disorder related to gluten intake, face constant challenges when it comes to adequate food, this is related to the scarcity of gluten-free processed foods on the market, forcing the consumers to resort to a homemade diet, spending more time preparing food at home. In Brazil, to guarantee the practice of a gluten-free diet, the Federative Republic of Brazil enacted Law 10,674 on May $16^{\text {th }}$, 2003, which determines that all industrialized foods must contain the inscriptions "contain gluten" or "does not contain gluten" (Brasil, 2003). 
The most common problem in the bakery industry is related to the high perishability and staling of bread. This staling phenomenon is associated with the migration of water from the crumb to the crust and subsequent evaporation, resulting in the retrogradation of the starch, which contributes to the increase in the firmness of the crumb, providing the sensation of a dry and firm product when consumed (Ortolan et al., 2015; Franco \& Silva, 2016; Bender \& Schönlechner, 2020; Schmiele, Sampaio \& Clerici, 2019). Thus, the freezing of the dough, followed by thawing, fermentation and baking in individual portions appears as an alternative for obtaining fresh products at any time.

The insertion of frozen dough in the gluten-free sector would make production more feasible, reducing costs, optimizing the process, and standardizing the products, reflecting in a better quality of the product offered to consumers. However, for the production of frozen doughs, maintaining the cell viability of yeasts during the freezing process and the cold chain and the correct defrosting of the dough must be considered (Rosell \& Gomez, 2007; Chen, Jansson, Lustrup \& Swenson, 2012; Ortolan et al., 2015), since the gluten-free dough has greater flowability and lower viscosity, due to the high amount of water required in the formulation (70 to $120 \%$ ). This additional water can damage the yeast cells through the formation of ice crystals during the freezing process and maintenance of the frozen dough. As an alternative to solve this problem, cryoprotectants can be used.

The term cryoprotectant is applied to designate the component that offers the microorganism a survival after the freezing and thawing process (Kunsler, 2017). The action of cryoprotectants on freezing is directly related to the formation of ice crystals and changes in the freezing point and the glass transition phase. The behavior of each cryoprotectant is linked to the chemical composition, for example, disaccharides increase the glass transition temperature, favoring the stability of the product before freezing. Cryoprotectants are classified according to the mechanism of action, which can be penetrating and non-penetrating agents (Nunes et al., 2015; Kenijz, Nesterenko \& Zayats, 2019).

Some examples of cryoprotectants most used in the cryopreservation of microorganisms are sucrose, trehalose, and glycerol. However, other substances, such as oligosaccharides and proteins and hydrolyzed proteins, have been studied as promising substances to be applied as cryoprotectants.

Freezing is an established food preservation process, to maintaining the nutritional characteristics of foods with satisfactory quality and safety and long shelf life. In general, the term freezing refers to the process in which the temperature decreases below the freezing point, while the term freezing is used to describe the subsequent state in which the food is kept, in other words, the maintenance of the food matrix below the freezing temperature during the cold chain (James, Purnell \& James, 2015).

The quality of bakery products produced from frozen doughs is largely influenced by the dough formulation, the mixing process (kneading) and the freezing parameters, such as: (i) freezing rate, (ii) storage temperature, and (iii) tawing speed (Čukelj \& Novotni, 2018).

During freezing, the sizes and shapes of the ice crystals formed can directly impact the cellular integrity of the food matrix and microorganisms. Parameters such as size, morphology and distribution of ice crystals are directly related to the conditions of the freezing rate applied to the process, affecting the nucleation and subsequent growing of ice crystals (Fellows, 2016). The freezing rate plays an important role in the final quality of the frozen products, determining both the number and the size of the ice crystals formed.

Fast freezing $\left(0.5\right.$ to $\left.3 \mathrm{~cm} \cdot \mathrm{h}^{-1}\right)$ allows the formation of microcrystals of ice, due to the sharp reduction in temperature, and with the reduced size of these crystals and the food matrix does not suffer damage. In slow freezing $\left(0.2 \mathrm{~cm} \mathrm{~h}^{-1}\right)$, the temperature is reduced slowly and gradually to the desired value, this promotes larger ice crystals development in relation to rapid freezing. Besides, it is not possible to have control of where the crystal formations occur, thus, during slow freezing, the formation of crystals occurs in both the intracellular and extracellular medium of the product, which can promote irreversible damage to the cell structure (Srinivasan \& Parkin, 2017). Intermediate freezing appears as an alternative to supply the deleterious 
effects that both slow and fast freezing can cause on the structure of the dough and/or on microorganisms. In this type of freezing, the initial formation of ice crystals promotes saturation of the extracellular medium of microorganisms, allowing the migration of intracellular water to the external environment (where are a greater concentration of solids), preventing the formation of ice crystals within yeast (Meziani et al., 2011; Meziani et al., 2012).

Despite being an excellent alternative for the bakery market, frozen storage can bring about unwanted changes in the technological characteristics of bread produced from the frozen dough (Ortolan et al., 2015; Bhattacharya, 2018). The ice crystals formed during the freezing can cause physical changes in the structure of food in the thawing, these changes are perceived by reducing the quality of the thawed food. In general, longer periods of frozen storage are associated with a higher rate of staling and harder crumb structure of the slices of bread, because of the reduction of the specific volume of loaves after the freezing, thawing, proofing, and baking process (Leonardi \& Azevedo, 2018; Čukelj \& Novotni, 2019).

The term cryoprotectant appeared by the Society of Cryobiology in 1965, created to designate the component that offers survival to the cell after the freezing-thawing process (Kunsler, 2017). The application of cryoprotectants in the freezing process is directly related to the formation of ice crystals. These substances act in reducing the melting point of the solution, modifying the freezing point and the glass transition temperature, to ensure that the freezing occurs only in the extracellular medium (Bhattacharya, 2018).

The specific performance of each cryoprotectant in the medium depends directly on the chemical composition, the main classification used is according to the mechanism of action, which can be intracellular (penetrating) and extracellular (nonpenetrating) cryoprotectants (Nunes et al., 2015; Kenijz et al., 2019).

Non-penetrating or extracellular cryoprotectants are molecules capable of inducing an increase in osmolarity in the external environment, promoting the migration of water from the intracellular to the extracellular environment, preventing the formation of intracellular ice crystals during freezing (Sola, Oliveira, Feistel \& Rezende, 2012; James et al., 2015). These substances are appropriate for the preservation of microorganisms, given the ability to cover the cell surface, forming a viscous layer capable of stabilizing the cell wall and the plasmatic membrane, minimizing, and repairing the possible damage caused by conservation and storage in low temperatures (Rinaldi, Paciulli, Caligiani, Scazzina \& Chiavaro, 2017; Tonetto, 2018).

Penetrating or intracellular cryoprotectants act on cells through their colligative properties, reducing the cryoscopic point. In this way, a greater amount of water remains in the liquid state at low temperatures, leading to a reduction in the intracellular concentration of solutes, providing a less harmful environment for microorganisms during freezing. These compounds can bind with water molecules, significantly reducing the formation and size of ice crystals (Sola et al., 2012; Motta, Paraguassú-Braga, Bouzas \& Porto, 2014)

Even with the proper application of cryoprotectants, other external factors can affect the quality of the doughs, such as i.e., variations in the temperature of the freezers and the consequent intracellular crystallization of the water, the interruption of the cold chain and the lack of control in the process.

The ability to make connections with water molecules are the main characteristics that make cryoprotectants attractive in protecting microorganisms against the adverse effects of freezing, with the compounds most used in food being: (i) low molecular weight carbohydrates (glucose, maltose, trehalose, sucrose and fructo-oligosaccharides); (ii) hydrocolloids (gums); (iii) organic compounds of the alcohol function (glycerol); (iv) low molar weight proteins with high water absorption capacity (Sola et al., 2012; Rosa \& Cruz, 2017; Macedo, Vimercati \& Araújo, 2020). The optimization of different types of cryoprotectants concerning concentrations and temperature has been developed to suit biological material.

The freezing of the dough affects mainly the cell viability of the yeast, and the main change occurs in the specific volume of the bread. This deleterious effect can be overcome with the application of cryoprotectants. Table 1 lists some studies that applied cryoprotective substances in frozen gluten dough and their main influence on bread quality. 
Table 1 - Studies with the application of cryoprotectants in the frozen dough with gluten and evaluation of the specific volume characteristics of bread.

\begin{tabular}{ll}
\hline Application in frozen doughs & References \\
\hline $\begin{array}{l}\text { The authors studied the application of antifreeze peptides from hydrolyzed pig skin collagen (CoAPPS) } \\
\text { applied in the cryopreservation of frozen dough and verified the reduction in specific volume after the }\end{array}$ & Chen, Wu, Li \& \\
freezing and thawing cycle of the dough. & Wang, 2017 \\
\hline $\begin{array}{l}\text { This study evaluated the cryoprotective capacity in gluten frozen dough of active substances such as } \\
\text { trehalose, chemical additives for bread dough (emulsifiers and ascorbic acid) and some enzymatic }\end{array}$ \\
\begin{tabular}{ll} 
complexes (glucose oxidase, lipases, xylanases, and fungal $\alpha$-amylases), reporting the decrease in specific & Halargada, 2017 \\
volume of bread produced from gluten frozen dough during the freezing and thawing cycle. & \\
\hline The authors studied the influence of $\alpha$-amylase, xylanase, cellulase, glucose oxidase and lipases in gluten & \\
frozen dough and evaluated the technological and sensory characteristics of the bread. They highlighted \\
that gluten frozen dough with glucose oxidase showed greater gas production, contributing to a greater \\
specific volume and better quality of the bread. Thermodynamic properties evaluated by differential
\end{tabular} & $\begin{array}{l}\text { Wang, } \\
\text { scanning calorimetry indicated that the addition of enzymes could contribute to the reduction of non- }\end{array}$ \\
freezing water, reducing the deleterious effects caused by the freezing and thawing of the dough causing & 2018 \\
an increase in the specific volume of the bread after the freezing and thawing cycle. & \\
\hline
\end{tabular}

Source: Chen, Wu, Li \& Wang, (2017); Halagarda, (2017); Wang, Pei, Teng \& Liang, (2018).

Thus, the goal of this study is to address the main challenges in the process of technological production of gluten-free frozen dough and present the main results obtained, aiming to highlight how these substances can influence the technological characteristics of frozen gluten-free dough and bread.

\section{Methodology}

This study was conducted using a scientific methodology for quantitative analysis and carried out in stages as proposed by Pereira, Shitsuka, Pereira and Shitsuka (2018).

\subsection{Raw materials used in the experiment}

The raw materials used were native rice flour, cassava starch, fresh yeast, sodium chloride, sucrose, and hydrogenated vegetable fat. The cryoprotectants applied were fructo-oligosaccharide, hydrolyzed soy protein and yeast extract.

\subsection{Standard formulation}

The standard formulation used was composed of the following concentrations: native rice flour (100\%), cassava starch $(10 \%)$, fresh yeast $(2.6 \%)$, sodium chloride $(1.6 \%)$, sucrose $(2.6 \%)$ and hydrogenated vegetable fat $(5.2 \%)$, in flour basis. The amount of water was added to achieve the ideal viscosity for the dough which was determined visually considering the standards stipulated by the same team member to minimize operator error. 


\subsection{Experimental design}

The amount of fructo-oligosaccharide, hydrolyzed soy protein and yeast extract were added at a concentration of $5 \%$, on flour basis, as outlined in a simplex-centroid mixture design (Table 2) (Rodrigues \& Iemma, 2014). A sample without cryoprotectant was used as a control.

Table 2 - Coded and real levels of the cryoprotectants for the simplex-centroid mixture design matrix for formulating the doughs.

\begin{tabular}{lllllll}
\hline \multirow{2}{*}{ Trial } & \multicolumn{5}{c}{ Coded value } & \multicolumn{5}{l}{ Real value (\%) } \\
\cline { 2 - 7 } & $\mathrm{x}_{1}$ & $\mathrm{x}_{2}$ & $\mathrm{x}_{3}$ & $\mathrm{X}_{1}$ & $\mathrm{X}_{2}$ & $\mathrm{X}_{3}$ \\
\hline $\mathbf{1}$ & 1.000 & 0.000 & 0.000 & 5.000 & 0.000 & 0.000 \\
$\mathbf{2}$ & 0.000 & 1.000 & 0.000 & 0.000 & 5.000 & 0.000 \\
$\mathbf{3}$ & 0.000 & 0.000 & 1.000 & 0.000 & 0.000 & 5.000 \\
$\mathbf{4}$ & 0.500 & 0.500 & 0.000 & 2.500 & 2.500 & 0.000 \\
$\mathbf{5}$ & 0.500 & 0.000 & 0.500 & 2.500 & 0.000 & 2.500 \\
$\mathbf{6}$ & 0.000 & 0.500 & 0.500 & 0.000 & 2.500 & 2.500 \\
$\mathbf{7}$ & 0.667 & 0.167 & 0.167 & 3.333 & 0.835 & 0.835 \\
$\mathbf{8}$ & 0.167 & 0.667 & 0.167 & 0.835 & 3.333 & 0.835 \\
$\mathbf{9}$ & 0.167 & 0.167 & 0.667 & 0.835 & 0.835 & 3.333 \\
$\mathbf{1 0}$ & 0.333 & 0.333 & 0.333 & 1.667 & 1.667 & 1.667 \\
$\mathbf{1 1}$ & 0.333 & 0.333 & 0.333 & 1.667 & 1.667 & 1.667 \\
$\mathbf{1 2}$ & 0.333 & 0.333 & 0.333 & 1.667 & 1.667 & 1.667 \\
\hline
\end{tabular}

$\mathrm{x}_{1}$ and $\mathrm{X}_{1}$ - fructo-oligosaccharide; $\mathrm{x}_{2}$ and $\mathrm{X}_{2}$ - hydrolyzed soy protein; $\mathrm{x}_{3}$ and $\mathrm{X}_{3}$ - yeast extract. Source: Autors (2021).

\subsection{Preparation of doughs and bread}

The dough was prepared in a single stage, taking all the ingredients in a PHP500 turbo mixer (Philco, Manaus, BRA), and mixing with a racket mixer at maximum speed for $10 \mathrm{~min}$. The doughs were divided into $100 \mathrm{~g}$ portions in aluminum pans with a dimension of width $(80 \mathrm{~mm})$, height $(30 \mathrm{~mm})$ and length $(110 \mathrm{~mm})$, and then half of the total samples were subjected to proofing and baking, and the other half to freeze in a domestic freezer and kept at $-18{ }^{\circ} \mathrm{C}$ for 7 days, packed in bioriented polypropylene packaging. After 7 days of storage, the thawing was performed in BOD (THELGA TF35-A), for 12 hours at 7 ${ }^{\circ} \mathrm{C}$. The proofing of the dough was carried out in BOD at $37{ }^{\circ} \mathrm{C}$ until the total filling of the aluminum pan, being then baked at $200{ }^{\circ} \mathrm{C}$ for 25 minutes, cooled for 2 hours at room temperature and packed in high-density polyethylene packages for further analysis.

\subsection{Technological aspects of the dough}

\subsubsection{Specific gravimetry}

The specific gravity of the dough (at day 0) was analyzed according to the American Association of Cereal Chemists International (AACCI) through the standard method 55-50.01 (AACCI, 2010). The analyses were performed in triplicate and the results were expressed in $\mathrm{g} . \mathrm{cm}^{-3}$.

\subsubsection{Proofing time}

The proofing time of the dough was evaluated by the time (in minutes) necessary for the leavening of the dough to complete the volume of the pan. The analysis was carried out without repetition. 


\subsubsection{Dough volume increase}

The understanding of the increase in the volume of the dough is directly related to the proofing rate, considering the amount of $\mathrm{CO}_{2}$ produced and retained in the dough. This data is essential to assess the performance of cryoprotectants after freezing and maintaining the cold chain. The doughs were analyzed for dough volume increase, based on the method and model (Eq. 1) proposed by Romano, Toraldo, Cavella and Masi (2007):

$$
\text { Dough volume increase }=[\mathrm{V}(\mathrm{t})-\mathrm{V}(0)] / \mathrm{V}(0) \quad \text { Eq. } 01
$$

Were: $\mathrm{V}(\mathrm{t})=$ Volume measured in the time lapse between the beginning of fermentation and the recording of the volume, and; $\mathrm{V}(0)=$ initial volume.

Approximately $50 \mathrm{~mL}$ of dough was added to a $250 \mathrm{~mL}$ graduate cylinder tube. The increase in the volume of the dough was recorded every 10 minutes for 50 minutes (day 0) and 100 minutes (day 7), where zero was the dough that was not subjected to freezing and 7 was the that was frozen and thawed after 7 days of freezing storage, in triplicate.

\subsection{Technological aspects of the bread}

\subsubsection{Specific volume}

The specific volume of the loaves was determined by the method of displacement of millet seeds as established by method 10-05.01 (AACCI, 2010), in triplicate, and the results expressed in L.kg-1.

\subsubsection{Firmness of crumb}

The firmness was evaluated through the method 74-09.01 (AACCI, 2010), using a TAXT Plus Texturometer (Haslemere, GBR), adopted with a P/36R cylindrical probe, force in compression mode, pre-test speed $1.0 \mathrm{~mm} . \mathrm{s}^{-1}$, test speed 1.0 $\mathrm{mm} . \mathrm{s}^{-1}$, post-test speed $10.0 \mathrm{~mm} \cdot \mathrm{s}^{-1}$ and distance of $40 \%$. The analysis was performed with 8 repetitions and the results expressed in N. This analysis was performed on bread slices, using 2 slices for each analysis, after 24 hours.

\subsubsection{Image analysis of the alveoli of the bread slices}

The bread slices image analysis was evaluated by the Image J software, as described by Tasiguano, Villarreal, Schmiele and Vernaza (2019). The alveoli average size $\left(\mathrm{mm}^{2}\right)$ and alveoli area (\%) was measured in triplicate.

\subsection{Statistical analysis}

The data obtained in the simplex-centroid mixture design were evaluated following the general mathematical model showed in Equation 2 (Rodrigues \& Iemma, 2014). Response Surface Methodology was applied to calculate the regression coefficient and analysis of variance (ANOVA) with a significance level of $10 \%$ and a minimum regression coefficient $\left(\mathrm{R}^{2}\right)$ of 0.80 was adopted. The optimal point was determined using the methodology proposed by Derringer and Suich (1980).

$$
\mathrm{Y}=\beta_{11} \mathrm{X}_{1}+\beta_{2} \mathrm{X}_{2}+\beta_{3} \mathrm{X}_{3}+\beta_{12} \mathrm{X}_{1} \mathrm{X}_{2}+\beta_{13} \mathrm{X}_{1} \mathrm{X}_{3}+\beta_{23} \mathrm{X}_{2} \mathrm{X}_{2}+\beta_{123} \mathrm{X}_{1} \mathrm{X}_{2} \mathrm{X}_{3}+\varepsilon \quad \text { (Eq. 2) }
$$

Where: $\mathrm{Y}=$ is the data recorded for the dependent variable; $\beta \mathrm{i}$ and $\beta \mathrm{ij}=$ are the regression coefficients for the pseudo component and binary and ternary mixtures, respectively; $\varepsilon=$ is the error; $x i$ and $x j=$ are coded values for the independent variables. 


\section{Results and Discussion}

\subsection{Technological aspects of the dough}

\subsubsection{Specific gravimetry}

The specific gravimetry is associated with the aeration level of the dough and the results $\left(1.08-1.13\right.$ g.cm $\left.{ }^{-3}\right)$ are shown in Table 3. Similar behavior was observed since no statistical difference was observed $(P>0.10)$ with the use of cryoprotectants in the dough formulation. This result indicates that the incorporation of air into the dough was homogeneous for all the trials and near to the control sample.

\subsubsection{Proofing time}

The results obtained (Table 3) for the trials were between 42 and 49 minutes for day 0 and between 35 and 64 minutes for day 7, with the control sample having a fermentation time of 43 and 100 minutes for days 0 and 7, respectively. However, the fermentation time showed no difference between the tests for day $0(P>0.10)$. However, after freezing and thawing $($ day 7$)$ it was observed that the best behavior aiming a lower fermentation time, which indicates a greater cryoprotective effect $\left(\mathrm{P}=0.002 ; \mathrm{F}_{\mathrm{cal}} / \mathrm{F}_{\mathrm{tab}} 5 ; 6 ; 0.10=5.13\right)$, occurred with the binary mixture between the fructo-oligosaccharides and the soy protein hydrolyzate $\left(\beta_{12}=-41.46\right)$ and the ternary combination between the three cryoprotectants studied $\left(\beta_{123}=-198.00\right)$, according to the mathematical model presented in Table 6 and observed in contour plot (Figure 1).

This behavior may be due to the greater effect of the formation of hydrogen bonds between fructo-oligosaccharides and water and the greater hydration capacity of soy protein hydrolyzate. The yeast extract action probably occurred because it is a medium in which the yeast has already developed, having suitable substances for the maintenance of yeast cell viability.

Table 3 - Specific gravimetry and proofing time of the dough obtained for the trials of the simplex-centroid mixture design and the control sample.

\begin{tabular}{llll}
\hline \multirow{2}{*}{ Trial } & Specific gravimetry* & Proofing time (minutes) & Day 7 \\
\cline { 2 - 4 } & Day 0 & 46 & 47 \\
\hline 1 & $1.13 \pm 0.02$ & 46 & 64 \\
2 & $1.11 \pm 0.02$ & 45 & 35 \\
3 & $1.11 \pm 0.02$ & 44 & 45 \\
4 & $1.10 \pm 0.01$ & 49 & 56 \\
5 & $1.11 \pm 0.01$ & 45 & 52 \\
6 & $1.13 \pm 0.02$ & 46 & 57 \\
7 & $1.11 \pm 0.01$ & 44 & 55 \\
8 & $1.08 \pm 0.02$ & 42 & 47 \\
9 & $1.10 \pm 0.01$ & 44 & 44 \\
10 & $1.09 \pm 0.01$ & 47 & 42 \\
11 & $1.11 \pm 0.02$ & 42 & 47 \\
12 & $1.09 \pm 0.01$ & 43 & 100 \\
Control & $1.11 \pm 0.01$ & 42 & 55 \\
\hline
\end{tabular}


Figure 1 - Contour plot for the proofing time (in minutes, for day 7) for the doughs with cryoprotectants addition fructooligosaccharides, soy protein hydrolysate and yeast extract.

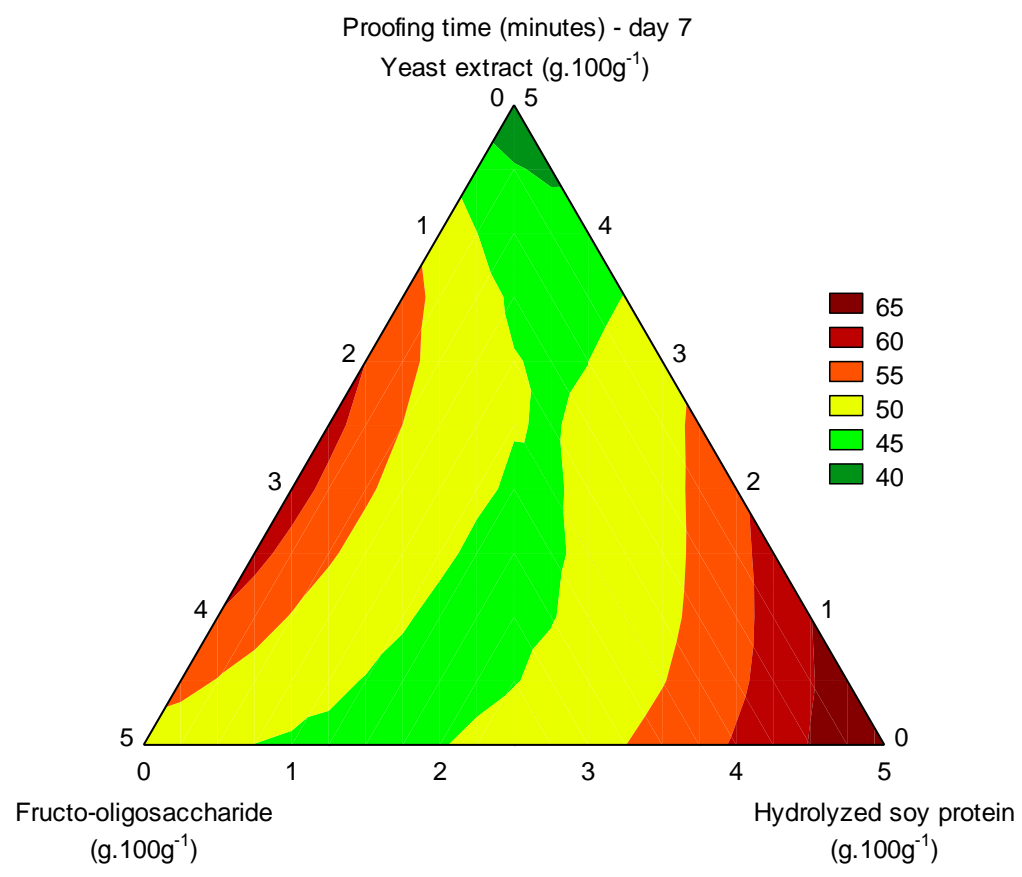

Source: Autors (2021).

\subsubsection{Dough volume increase}

The results obtained for dough volume increase were used to generate the curves presented in Figure 2 and the area under curve (AUC) determined and the results obtained are shown in Figure 3. This figure represents the behavior of the dough proofing curve increase on days 0 and 7. The freeze/thawing process promotes a decrease in yeast's fermentation power. However, after freezing, maintaining the cold chain, and thawing, it was found that all the trials showed a higher volume increase of the dough when compared to the control sample, indicating that there was a cryoprotective effect for all substances in isolation and/or combined. 
Figure 2 - Curves of dough volume increase for the control sample (C) and the trials for the mixture design on day 0 (at the top) and day 7 (at the bottom).

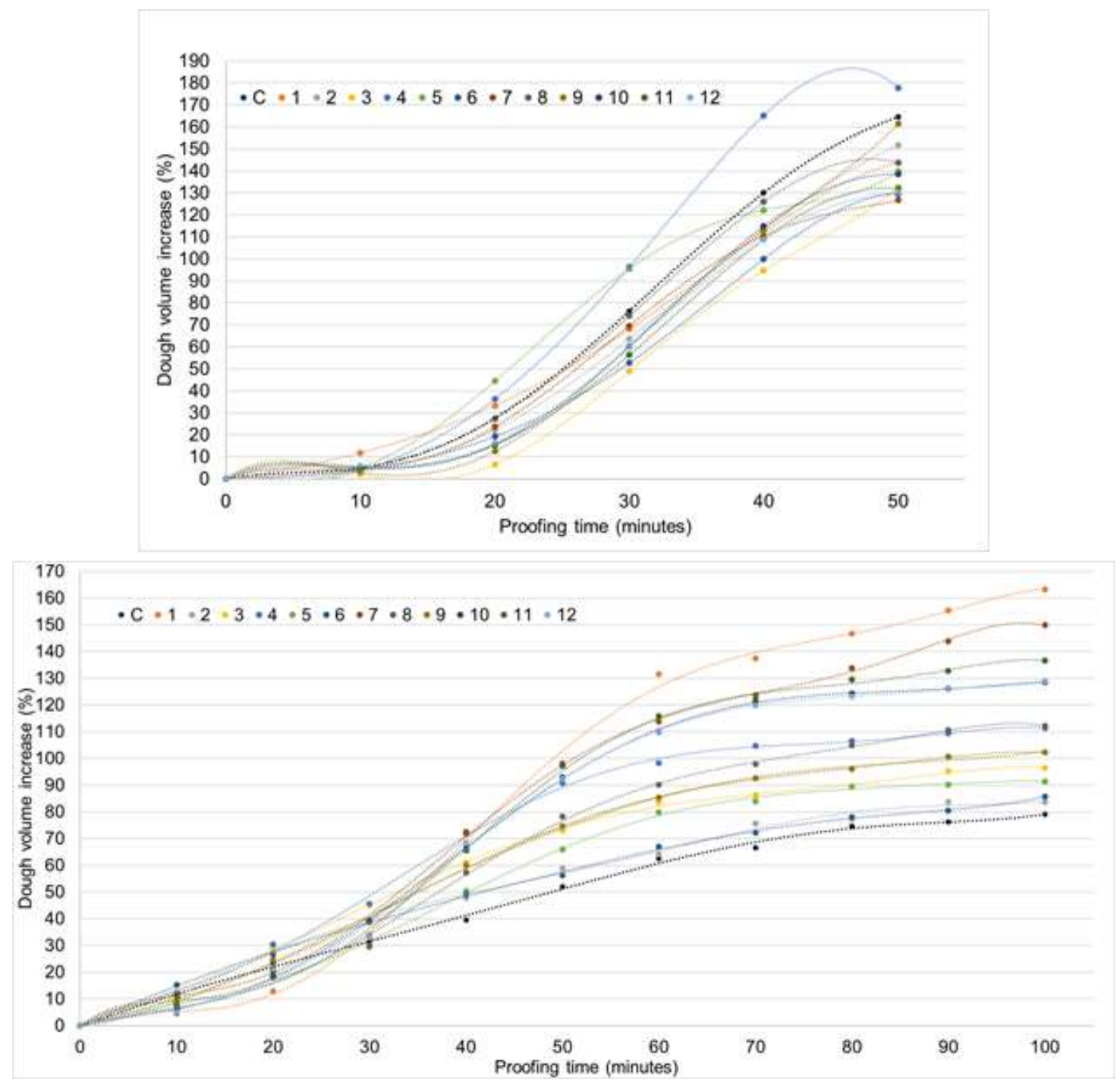

Means recorded from three repetitions. Source: Autors (2021).

After freezing and thawing the dough, the best results were obtained with higher concentrations of fructooligosaccharides and lower (day 0) and intermediate (day 7) levels of hydrolyzed soy protein, with yeast extract having a little effect (Figure 4). As observed in the mathematical models (Table 6), the increase in dough volume on day zero (before freezing) performed better with the binary mixtures between the fructo-oligosaccharides and the hydrolyzed soy protein $\left(\beta_{12}=3977\right)$ and the fructo- oligosaccharides and yeast extract $\left(\beta_{13}=3068\right)\left(P=0.012 ; \mathrm{F}_{\text {cal }} / \mathrm{F}_{\text {tab } 5 ; 6 ; 0.10}=2.65\right)$. In addition, a deleterious effect was observed by the ternary components $\left(\beta_{123}=-22897\right)$, resulting in a drastic drop in the fermentation power. However, we can highlight the increase in the fermentative power and with a synergic action of the ternary combination $\left(\beta_{123}=55480\right)$ among the cryoprotectants in the increase of the volume of the dough after freezing and thawing (day 7), since this study has the goal of the maintenance of cell viability and fermentative power of yeast. There was also a positive effect on the increase in mass volume provided by the fructo-oligosaccharide $\left(\beta_{1}=8934\right)\left(P<0.001 ; \mathrm{F}_{\mathrm{cal}} / \mathrm{F}_{\mathrm{tab} 5 ; 6 ; 0.10}=28.19\right)$.

This behavior can be associated with the greater effect of the formation of hydrogen bonds of fructo-oligosaccharides with water and the greater hydration capacity of the hydrolyzed soy protein (Schmiele, Felisberto, Clerici \& Chang, 2017). 
In addition, the fructo-oligosaccharides can have an osmotic effect in the environment, changing the portion of non-freezing water (Srinivasan \& Parkin, 2017; Wong, 2018).

Figure 3 - Results of the expansion volume of the dough on days 0 and 7 of the control sample (C) and the trials for the experimental design using the cryoprotectants, expressed in area under curve.

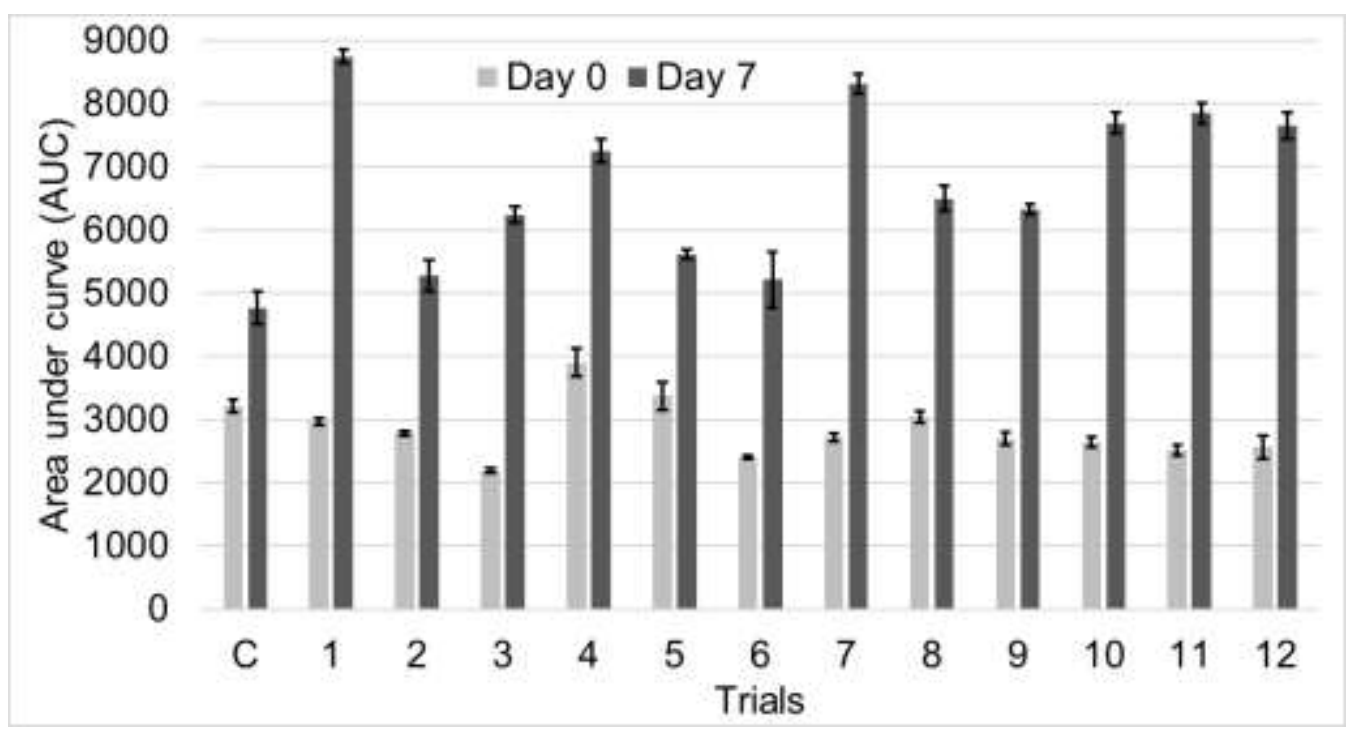

Means of three repetitions \pm standard deviation represented by the vertical bars. Source: Authors (2021).

Thus, when the free water crystallizes, ice crystals are formed and the remaining concentration of the solute in the liquid phase increases. These changes promote a reduction in the freezing point of the dough, reducing intracellular mobility, contributing to the reduction of free water available in the medium for the formation of ice crystals (Srinivasan \& Parkin, 2017). In addition to the osmotic effect provided by fructo-oligosaccharides, this substance has greater solubility and water retention capacity, does not crystallize, does not precipitate, and can be used to change the freezing temperature of food (Macedo et al., 2020).

The fructo-oligosaccharides are highly hygroscopic, so they can be applied to products to increase humectant and water bonding and decrease water activity, ensuring an increase in microbiological stability (Rosa \& Cruz, 2017; Xavier-Santos, Bedani, Perego, Converti \& Saad, 2019). 
Figure 4 - Contour plots for dough volume increase for the trials from the simplex-centroid mixture design using the cryoprotectants on day 0 (at the top) and day 7 (at the bottom)
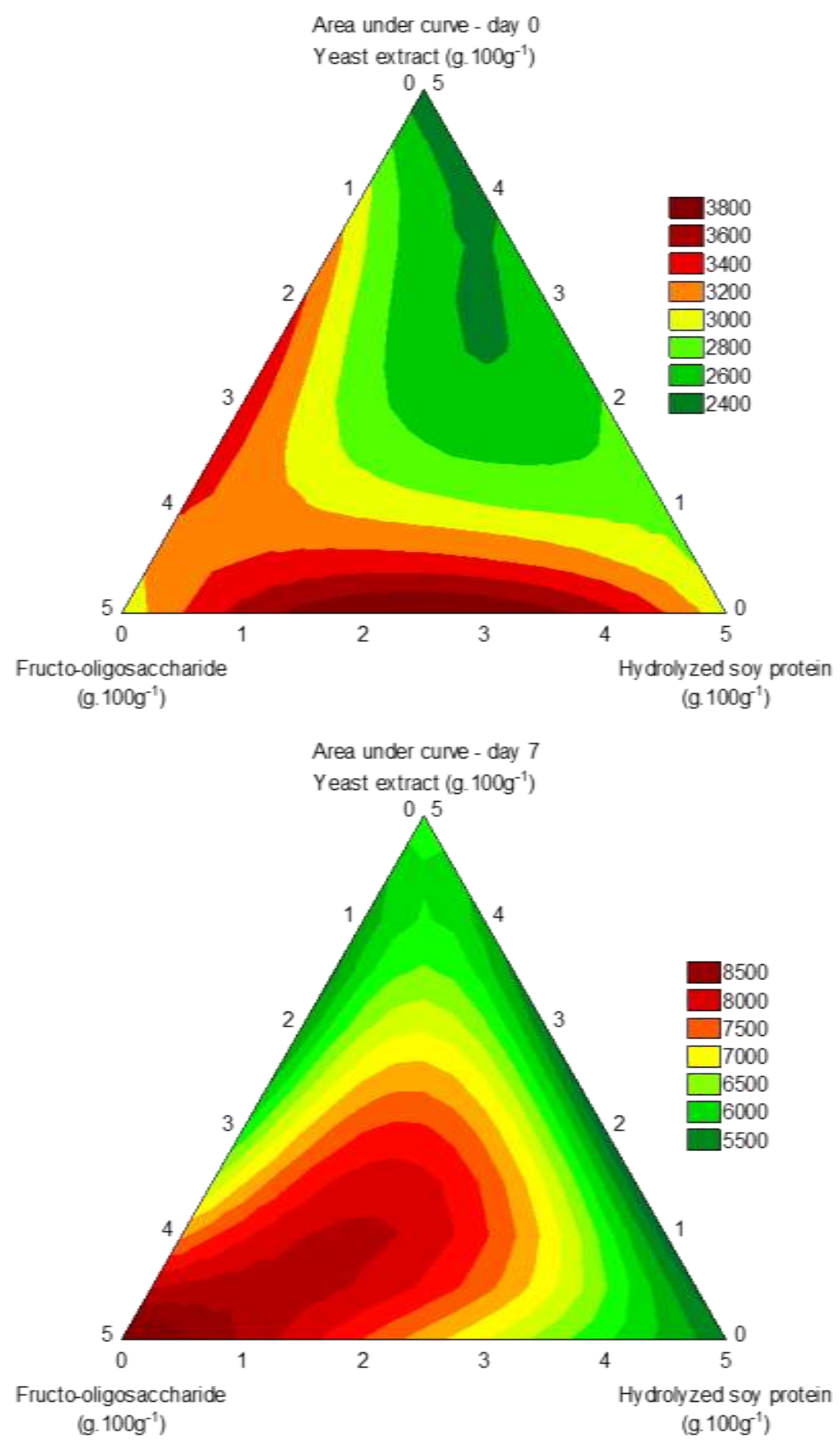

Source: Authors (2021).

A study performed by Park, Jang \& Lim (2016) showed that the addition of 3 to $9 \%$ of fructo-oligosaccharides to the dough of frozen bread (with gluten) showed significant improvements in important aspects of the quality of bread, with an improvement in the quality of the baking of the dough, even after storage for up to eight weeks stocked at $-18^{\circ} \mathrm{C}$, resulting in an increase in specific volume and a reduction in hardness, with the addition of $6 \%$ fructo-oligosaccharides showing the best effect 
on the quality of the dough. Also, the use of fructo-oligosaccharides as a cryoprotective substance can be applied to other products, such as chocolates, yogurts, and mousses, promoting improvements in the desired characteristics.

\subsection{Technological aspects of the bread}

\subsubsection{Specific volume}

The specific volume is one of the first indicator parameters of the quality of the bread produced and directly depends on the expansion of the volume of the dough during fermentation and the oven rise phenomenon in the cooking process (Brites, Schmiele \& Steel, 2018; Packkia-Doss, Chevallier, Pare \& Le-Bail, 2019). The specific volume of the bread in the trials of the experimental design ranged between 1.28 and $3.38 \mathrm{~L} \mathrm{~kg}^{-1}$ for the bread obtained from the doughs without freezing and between 1.66 and $3.14{\mathrm{~L} . \mathrm{kg}^{-1}}^{-1}$ for the bread obtained from the doughs after freezing and thawing (Table 4).

Table 4 - Specific volume and crumb firmness of the bread obtained for the trials of the simplex-centroid mixture design and the control sample.

\begin{tabular}{|c|c|c|c|c|}
\hline \multirow{2}{*}{ Trial } & \multicolumn{2}{|c|}{ Specific volume $\left({\left.\mathrm{L} . \mathrm{kg}^{-1}\right)^{*}}^{*}\right.$} & \multicolumn{2}{|c|}{ Firmness $(\mathbf{N})^{* *}$} \\
\hline & Day 0 & Day 7 & Day 0 & Day 7 \\
\hline 1 & $3.03 \pm 0.15$ & $2.90 \pm 0.01$ & $13.16 \pm 1.55$ & $21.14 \pm 1.88$ \\
\hline 2 & $1.73 \pm 0.11$ & $1.66 \pm 0.05$ & $14.68 \pm 1.39$ & $24.06 \pm 2.13$ \\
\hline 3 & $1.28 \pm 0.14$ & $2.90 \pm 0.01$ & $14.86 \pm 1.30$ & $21.41 \pm 1.43$ \\
\hline 4 & $2.35 \pm 0.19$ & $3.09 \pm 0.06$ & $12.13 \pm 1.43$ & $15.00 \pm 2.02$ \\
\hline 5 & $3.12 \pm 0.18$ & $3.05 \pm 0.11$ & $10.60 \pm 1.02$ & $10.85 \pm 1.28$ \\
\hline 6 & $1.87 \pm 0.05$ & $1.71 \pm 0.03$ & $14.11 \pm 1.54$ & $22.42 \pm 1.65$ \\
\hline 7 & $3.38 \pm 0.12$ & $3.14 \pm 0.05$ & $11.22 \pm 1.46$ & $12.73 \pm 1.88$ \\
\hline 8 & $3.33 \pm 0.22$ & $1.89 \pm 0.01$ & $14.57 \pm 1.71$ & $20.98 \pm 1.45$ \\
\hline 9 & $1.89 \pm 0.07$ & $1.65 \pm 0.01$ & $15.19 \pm 1.38$ & $21.63 \pm 3.32$ \\
\hline 10 & $2.31 \pm 0.07$ & $1.82 \pm 0.10$ & $14.32 \pm 0.89$ & $18.61 \pm 2.48$ \\
\hline 11 & $2.33 \pm 0.10$ & $1.85 \pm 0.04$ & $14.30 \pm 1.10$ & $18.73 \pm 1.23$ \\
\hline 12 & $2.32 \pm 0.11$ & $1.84 \pm 0.20$ & $14.81 \pm 1.98$ & $19.36 \pm 2.12$ \\
\hline Control & $2.85 \pm 0.10$ & $2.41 \pm 0.07$ & $12.08 \pm 2.68$ & $26.91 \pm 3.42$ \\
\hline
\end{tabular}

*Means of three repetitions \pm standard deviation. **Means of eight repetitions \pm standard deviation. Source: Authors (2021).

We believe it is important to note that trials 3 and 4 showed higher specific volumes on day 7 when compared to day 0 . This indicates that yeast extract and the interaction of fructo-oligosaccharide with hydrolyzed soy protein showed promising properties. As noted in Table 6, of the mathematical models, and in the behavior of the contour plots (Figure 5), we found that bread with higher specific volume was obtained from the doughs without freezing and was obtained with the binary mixture between the fructo-oligosaccharide and the yeast extract $\left(\beta_{13}=3.68\right)$ and the isolated effect of fructo-oligosaccharides $\left(\beta_{1}=3.12\right)$ $\left(P=0.001 ; \mathrm{F}_{\mathrm{cal}} / \mathrm{F}_{\mathrm{tab} 5 ; 6 ; 0.10}=5.97\right)$. After freezing and thawing the doughs it was found that the higher specific volumes were achieved with the binary mixture of the fructo-oligosaccharides with the hydrolyzed soy protein $\left(\beta_{12}=3.48\right)$, followed by the isolated effect of the fructo-oligosaccharides $\left(\beta_{1}=3.08\right)\left(P=0.006 ; \mathrm{F}_{\mathrm{cal}} / \mathrm{F}_{\mathrm{tab}} ; ; 6 ; 0.10=3.50\right)$. 
Figure 5 - Contour plots for specific volume for the trials from the simplex-centroid mixture design using the cryoprotectants on day 0 (at the top) and day 7 (at the bottom).
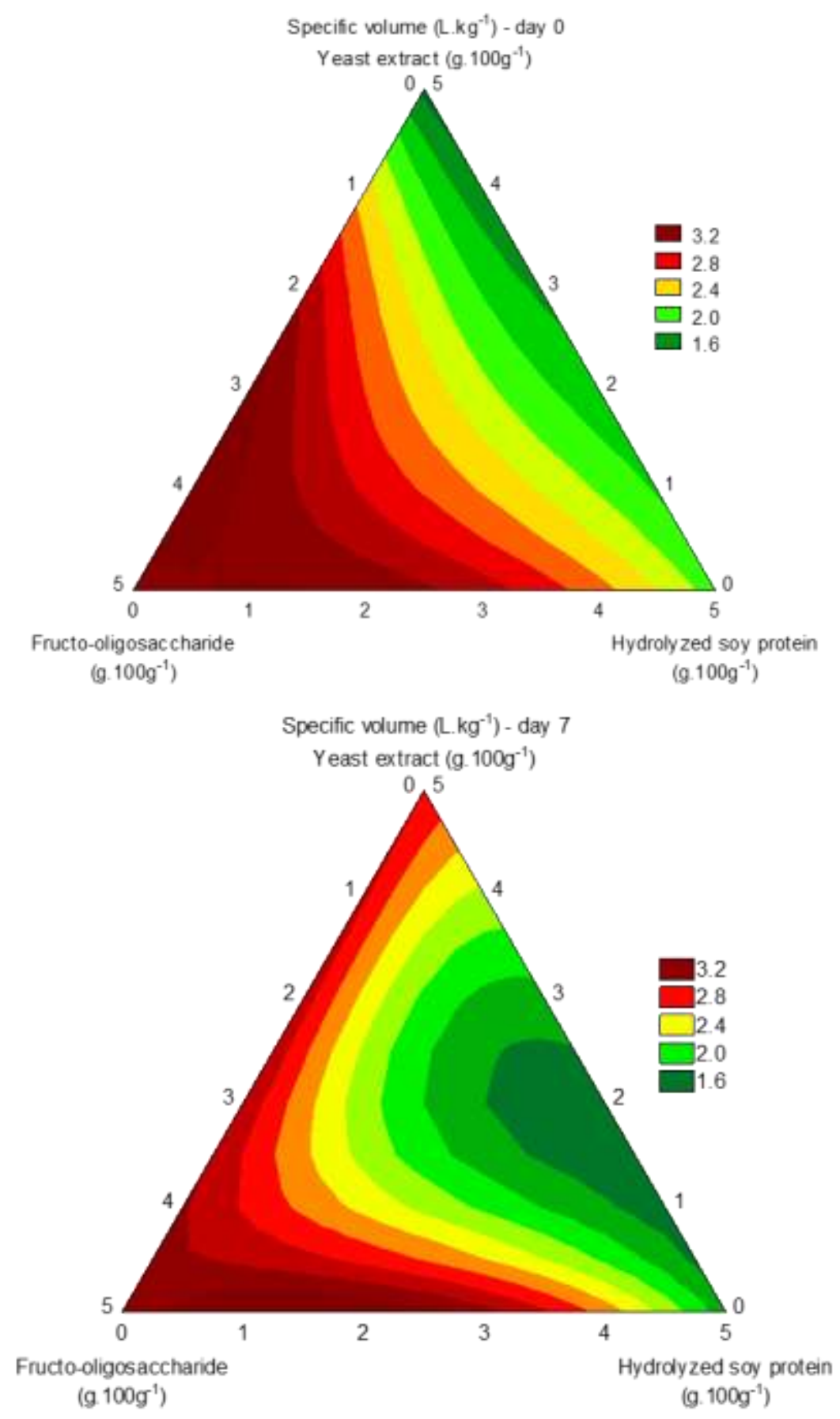

Source: Authors (2021).

The results indicated that the increase in the concentration of fructo-oligosaccharides and the decrease in hydrolyzed soy protein provided bread with higher specific volumes, with the yeast extract having the least effect, especially when combined with the fructo-oligosaccharides and hydrolyzed soy protein for the bread obtained on day 0. It is after freezing and thawing (day 7), it was observed that the best results were chosen with greater fructo-oligosaccharides and use of hydrolyzed soy protein of up to $3 \%$ (Figure 5). The yeast extract showed a positive effect when used at the highest concentration, while still observing a combined effect of the yeast extract with the other independent variables resulting in a reduction in the specific volume. 
The reduction in specific volume during the freezing and thawing cycle is associated with the formation of ice crystals that are formed mainly into the yeast, resulting in a reduction in the yeast's fermentative power and survival during the frozen storage stage (Ding et al., 2015). Although this reduction occurs, cryoprotective substances prevented the more severe reduction of this parameter. Few studies evaluate how the application of cryoprotective substances behave when added to the frozen dough, it is how the properties of each substance can interfere with the specific volume characteristics of bread.

\subsubsection{Firmness of crumb}

According to the data showed in Table 4, the firmness values ranged between 10.60 and $15.19 \mathrm{~N}$ for the bread crumb of the experimental design trials before freezing. After the freezing and thawing stage, the crumb firmness of the bread of the trials ranged between 10.85 and $24.06 \mathrm{~N}$. The control sample showed a crumb firmness of 12.08 and $26.91 \mathrm{~N}$ for bread without freezing and after freezing and thawing the doughs, respectively, which increased by $122.73 \%$. As shown in Table 6 , the binary mixtures between the fructo-oligosaccharides with the hydrolyzed soy protein $\left(\beta_{12}=-7.58\right)$ or with the yeast extract $\left(\beta_{13}=-\right.$ 13.47) showed the best synergistic effect for the bread crumb firmness before the dough freeze $\left(P=0.013 ; \mathrm{F}_{\text {cal }} / \mathrm{F}_{\text {tab } 5 ; 6 ; 0.10}=\right.$ 2.51). After the freezing/thawing stage, the bread crumb was improved by the binary mixture between the fructo-oligosaccharides and the yeast extract $\left(\beta_{13}=-2.62\right)$ and by the ternary combination between the cryoprotectants $\left(\beta_{123}=-20.76\right)(P=0.005$; $\mathrm{F}_{\text {cal }} / \mathrm{F}_{\text {tab } 5 ; 6 ; 0.10}=3.76$ ).

The best effects on the firmness results can be seen with higher concentrations of fructo-oligosaccharides and lower levels of hydrolyzed soy protein (Figure 6), with the yeast extract having a lower effect on this characteristic, which aims at loaves with greater softness. When analyzing the texture of the bread on day 7 , it was observed that the best concentration of fructo-oligosaccharides and hydrolyzed soy protein was approximately 3 and $2 \%$, respectively, where the use of yeast extract did not favor the formation of a soft crumb.

The polymeric arrangements of the components present in the dough are mainly affected by changes in water mobility and the formation of ice crystals during frozen storage, and starch retrogradation is the main cause of bread staling, which happens more rapidly in bread produced from frozen dough when compared to non-frozen dough bread (Park et al., 2016; Maity, Saxena \& Raju, 2017; Wong, 2018; He et al., 2020). With the reduction of temperature, the interaction of water with other polymers increases, until the so-called maximum rate region, which occurs at around $4{ }^{\circ} \mathrm{C}$ in the dough. Thus, the act of freezing and defrosting a dough is equivalent to about 24 hours of staling at $20^{\circ} \mathrm{C}$, because the product is submitted twice through the maximum region of the interaction of water-polymers (during freezing and thawing) (Kringel, Filipini \& Salas-Mellado, 2017). This effect may be related to the rearrangement of amylose in the dough matrix during the frozen storage process, to make it more susceptible to association with the water available in the intracellular medium, this interaction between starch and water contributes to the increase of firmness of the loaves after thawing (He et al., 2020). 
Figure 6 - Contour plots for crumb firmness for the trials from the simplex-centroid mixture design using the cryoprotectants on day 0 (at the top) and day 7 (at the bottom).

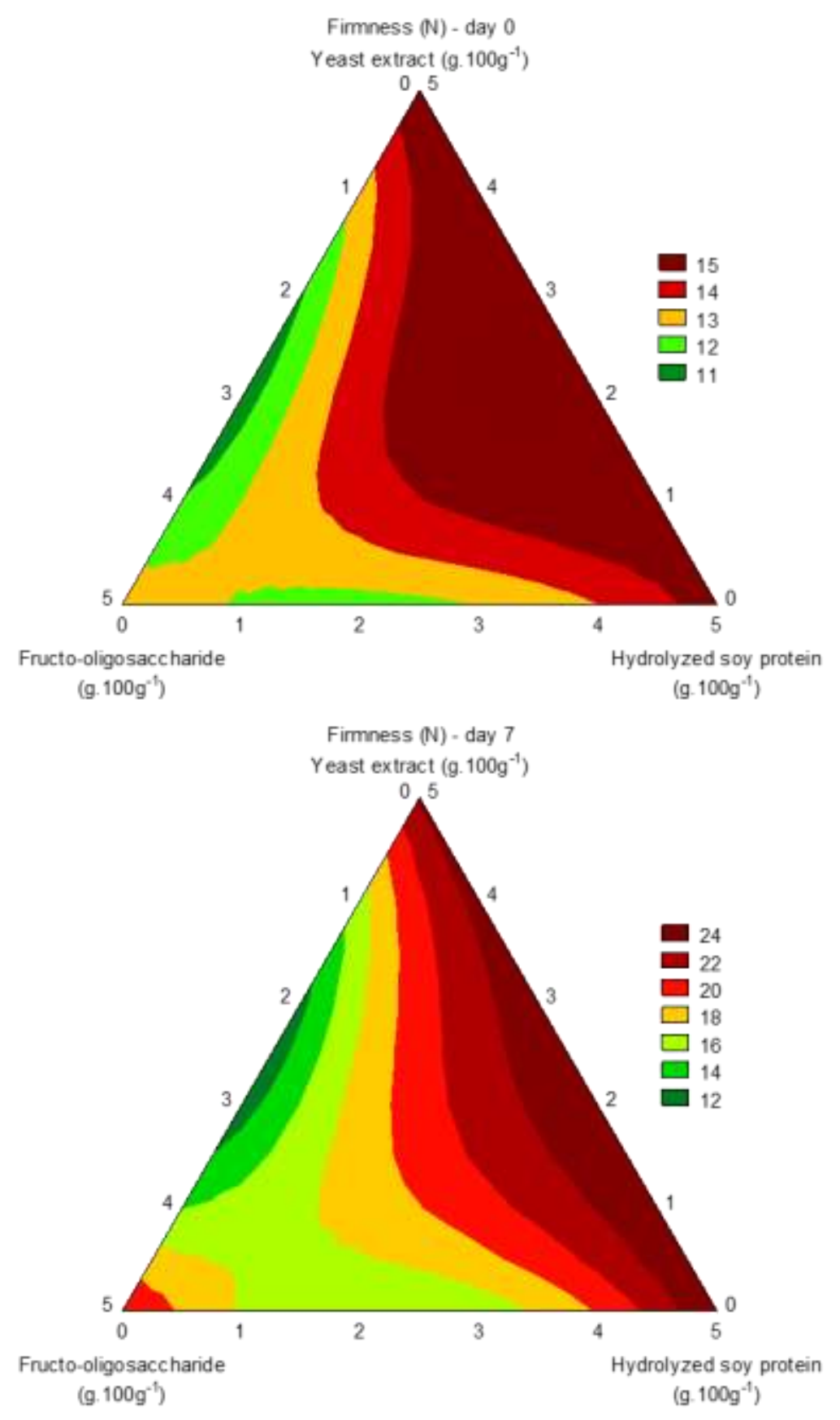

Source: Authors (2021).

\subsubsection{Image analysis of the alveoli of the bread slices}

The bread slices image analysis was evaluated by the Image $\mathbf{J}$ software, as described by (Tasiguano, Villarreal, Schmiele \& Vernanza, 2019). The alveoli average size $\left(\mathrm{mm}^{2}\right)$ and alveoli area (\%) was measured in triplicate. Image analysis is considered as an extension of the first visual impressions that the product makes to the consumer. As it is possible to see through Figure 7 , in which it showed that the samples after thawing, proofing, and baking showed a difference in the central collapse and a more attractive and uniform alveolar structure with the naked eye, with more regular alveoli than in the samples of day 0 . This behavior presents itself as a synergistic advantage with the manufacture of frozen dough. 
Figure 7 - Contour plots for crumb firmness for the trials from the simplex-centroid mixture design using the cryoprotectants
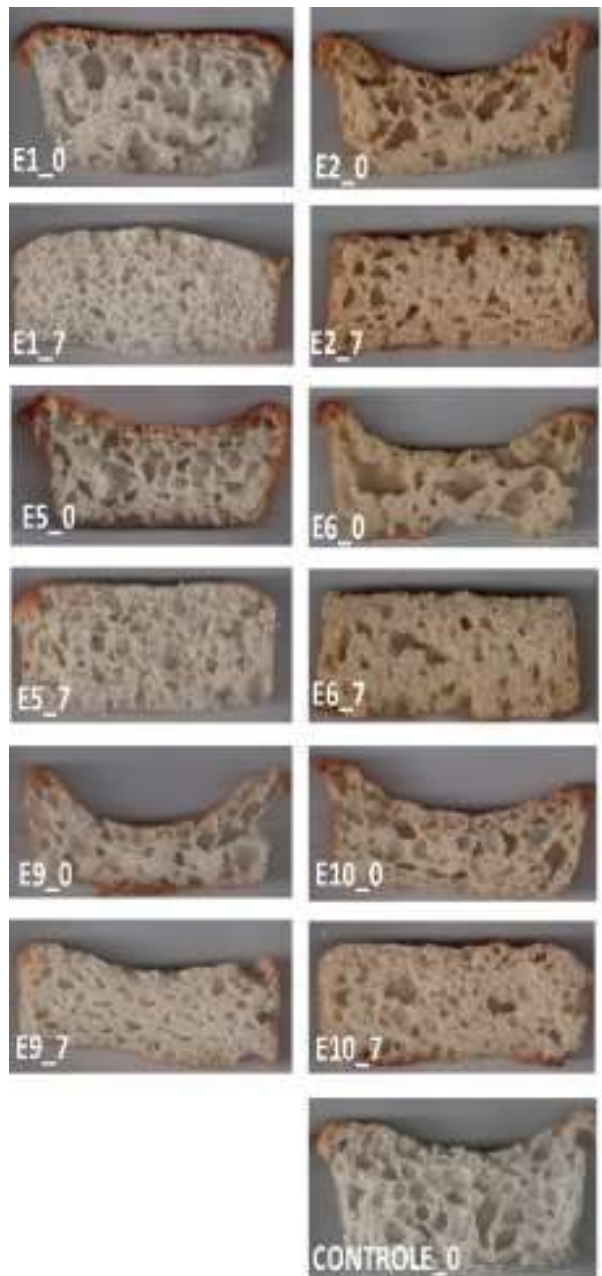
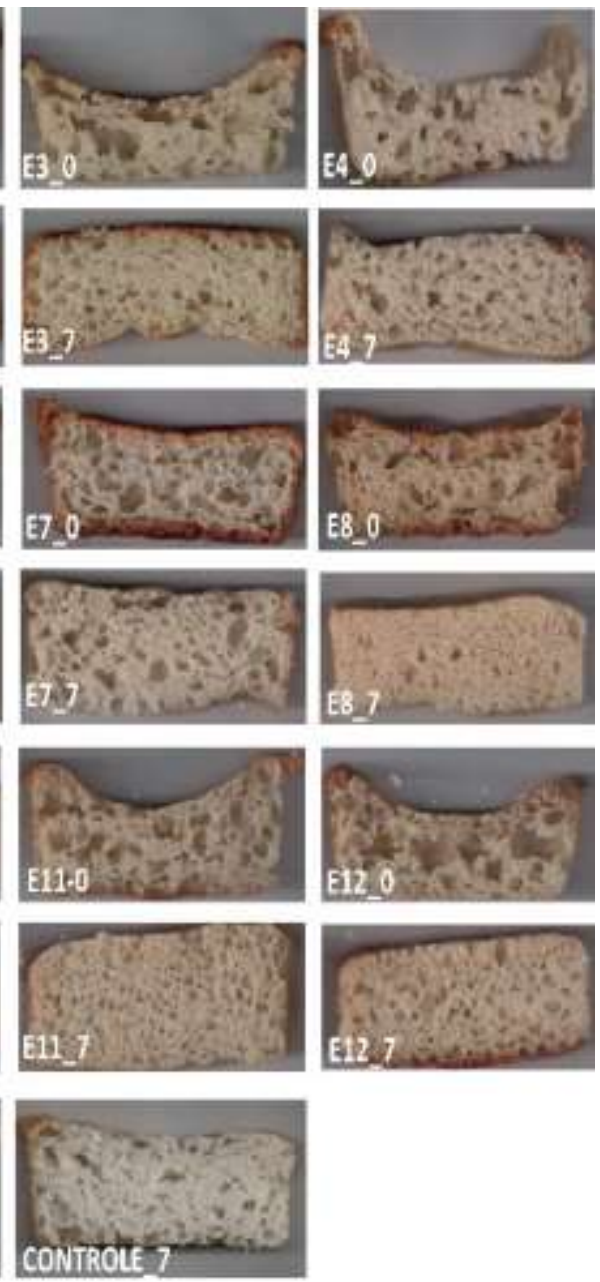

Letter " $E$ " represents the trial, the number after the "E" represents the trial number and the last number represents the day $(0$ for the bread from the dough without freezing and 7 for the bread from dough after freeze/thawing step). "Controle" is the control sample. Source: Authors (2021).

The experimental data obtained from the trials for the alveoli average size and the alveoli area are shown in Table 5 . The results ranged between 67.17 and $107.35 \mathrm{~mm}^{2}$ for day 0 and between 44.87 and $88.48 \mathrm{~mm}^{2}$ for day 7 for the alveoli of the bread slices after the freeze/thaw step. It is desirable to have many alveoli but with smaller sizes (Souza et al., 2018).

Thus, the effects with higher regression coefficients presented by the mathematical models (Table 6) allow inferring that the binary mixtures of the hydrolyzed soy protein with the fructo-oligosaccharides $\left(\beta_{12}=-95.78\right)$ and with the yeast extract

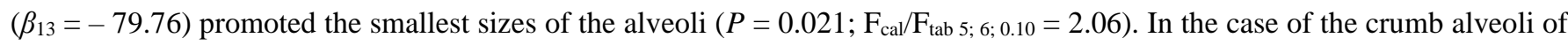
the bread slices after freezing/thawing the doughs, the best effect was provided by the combination of the three cryoprotectants studied - ternary mixture $\left(\beta_{123}=-255.97\right)\left(P=0.007 ; \mathrm{F}_{\text {cal }} / \mathrm{F}_{\text {tab } 5 ; 6 ; 0.10}=3.20\right)$. 
Table 5 - Alveoli average size and alveoli area of the bread slices obtained for the trials of the simplex-centroid mixture design and the control sample

\begin{tabular}{lllll}
\hline \multirow{2}{*}{ Trial } & \multicolumn{3}{l}{ Alveoli average size $\left(\mathbf{m m}^{2}\right)$} & Alveoli area $\mathbf{( \% )}$ \\
\cline { 2 - 5 } & Day 0 & Day 7 & Day 0 & Day 7 \\
\hline 1 & $107.35 \pm 9.11$ & $79.31 \pm 3.84$ & $44.25 \pm 3.56$ & $33.05 \pm 1.78$ \\
2 & $95.51 \pm 7.78$ & $57.02 \pm 5.52$ & $39.27 \pm 3.20$ & $23.64 \pm 2.29$ \\
3 & $68.92 \pm 12.38$ & $56.44 \pm 2.64$ & $28.34 \pm 5.09$ & $23.40 \pm 1.10$ \\
4 & $72.03 \pm 5.32$ & $69.95 \pm 7.97$ & $29.78 \pm 2.22$ & $29.00 \pm 3.30$ \\
5 & $96.79 \pm 11.90$ & $88.48 \pm 10.21$ & $40.13 \pm 4.93$ & $36.68 \pm 5.21$ \\
6 & $67.17 \pm 12.41$ & $44.87 \pm 5.20$ & $27.70 \pm 4.23$ & $19.02 \pm 5.16$ \\
7 & $101.33 \pm 7.47$ & $83.89 \pm 16.07$ & $42.89 \pm 2.15$ & $34.78 \pm 2.90$ \\
8 & $80.45 \pm 5.23$ & $50.33 \pm 4.45$ & $33.18 \pm 6.66$ & $20.87 \pm 2.28$ \\
9 & $91.61 \pm 12.63$ & $53.74 \pm 4.92$ & $37.67 \pm 5.19$ & $22.28 \pm 2.04$ \\
10 & $100.57 \pm 20.23$ & $66.70 \pm 10.19$ & $41.47 \pm 8.34$ & $27.65 \pm 4.22$ \\
11 & $90.75 \pm 13.82$ & $72.71 \pm 7.85$ & $37.51 \pm 5.53$ & $30.15 \pm 3.26$ \\
12 & $107.27 \pm 23.34$ & $72.24 \pm 5.58$ & $44.85 \pm 10.14$ & $29.95 \pm 2.31$ \\
Control & $103.16 \pm 7.22$ & $51.86 \pm 6.71$ & $42.99 \pm 3.94$ & $21.50 \pm 2.78$ \\
\hline
\end{tabular}

Means of eight repetitions \pm standard deviation. Source: Authors (2021).

The alveoli area was higher in the crumb obtained from the slices without the freezing process. The values for the trials ranged between 27.70 and $44.85 \%$. According to the mathematical model (Table 6), the fructo-oligosaccharides improved the alveoli area $\left(\beta_{1}=44.72\right)$, followed by the hydrolyzed soy protein $\left(\beta_{2}=38.63\right)\left(P=0.003 ; \mathrm{F}_{\mathrm{cal}} / \mathrm{F}_{\mathrm{tab}} 4 ; 7 ; 0.10=4.17\right)$. After the freezethawing process, the alveoli area of the trials ranged between 19.02 and $36.68 \%$. The binary mixture between fructooligosaccharides and yeast extract $\left(\beta_{13}=45.42\right)$ and the pseudo component regarding hydrolyzed soy protein $\left(\beta_{2}=37.87\right)$ performed the higher alveoli area $\left(P=0.008 ; \mathrm{F}_{\text {cal }} / \mathrm{F}_{\text {tab } 5 ; 6 ; 0.10}=3.13\right)$.

Figure 8 shows the contour plot of the alveoli average size and Figure 9 of the alveoli area. It was observed that on days 0 , the smallest alveolar sizes were found with the use of yeast extract and lower levels of hydrolyzed soy protein. When we analyzed day 7 , the contour plot indicated that the higher levels of hydrolyzed soy protein and the lower amount of yeast extract, the smaller alveoli size was obtained. This behavior is a character with better quality for the product and with higher acceptance by consumers (Silveira, Cardoso \& Schmiele, 2019). The formation of the alveoli is directly related to the incorporation of air in the dough during the mixing stage, by the production of $\mathrm{CO}_{2}$ during the proofing step and by the diffusion of the gas released in the aqueous phase to provide the growth of the air bubbles present in the dough. Besides, the size and uniformity of the alveoli reflect directly on the specific volume of the loaves and the softness of the crumb (Neves et al., 2020; Neves, Gomes \& Schmiele, 2020). 
Research, Society and Development, v. 10, n. 3, e44510313556, 2021

(CC BY 4.0) | ISSN 2525-3409 | DOI: http://dx.doi.org/10.33448/rsd-v10i3.13556

Figure 8 - Contour plots for alveoli average size for bread slices of the trials from the simplex-centroid mixture design using the cryoprotectants on day 0 (at the top) and day 7 (at the bottom).

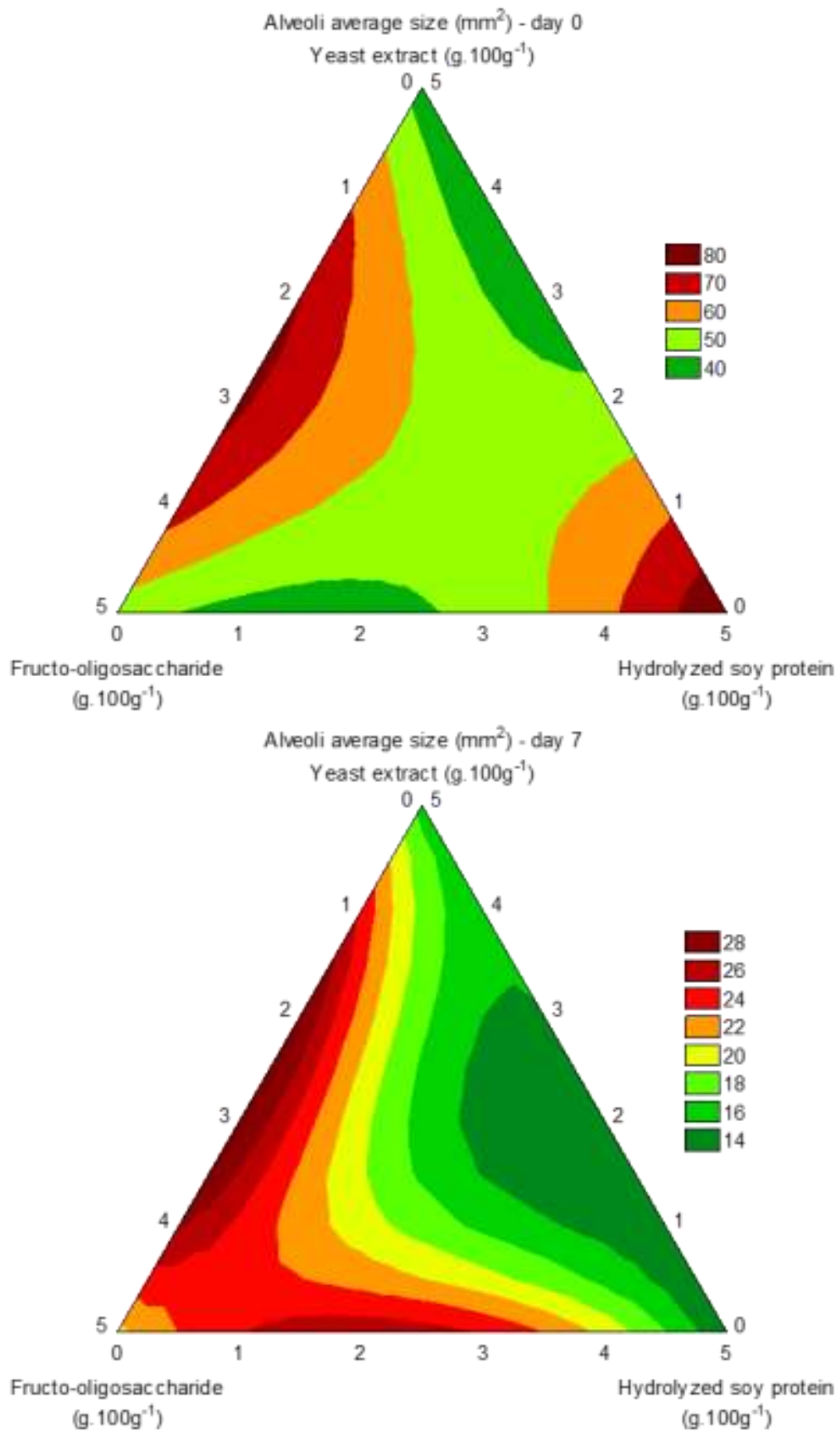

Source: Authors (2021). 
Research, Society and Development, v. 10, n. 3, e44510313556, 2021

(CC BY 4.0) | ISSN 2525-3409 | DOI: http://dx.doi.org/10.33448/rsd-v10i3.13556

Figure 9 - Contour plots for alveoli area for bread slices of the trials from the simplex-centroid mixture design using the cryoprotectants on day 0 (at the top) and day 7 (at the bottom).
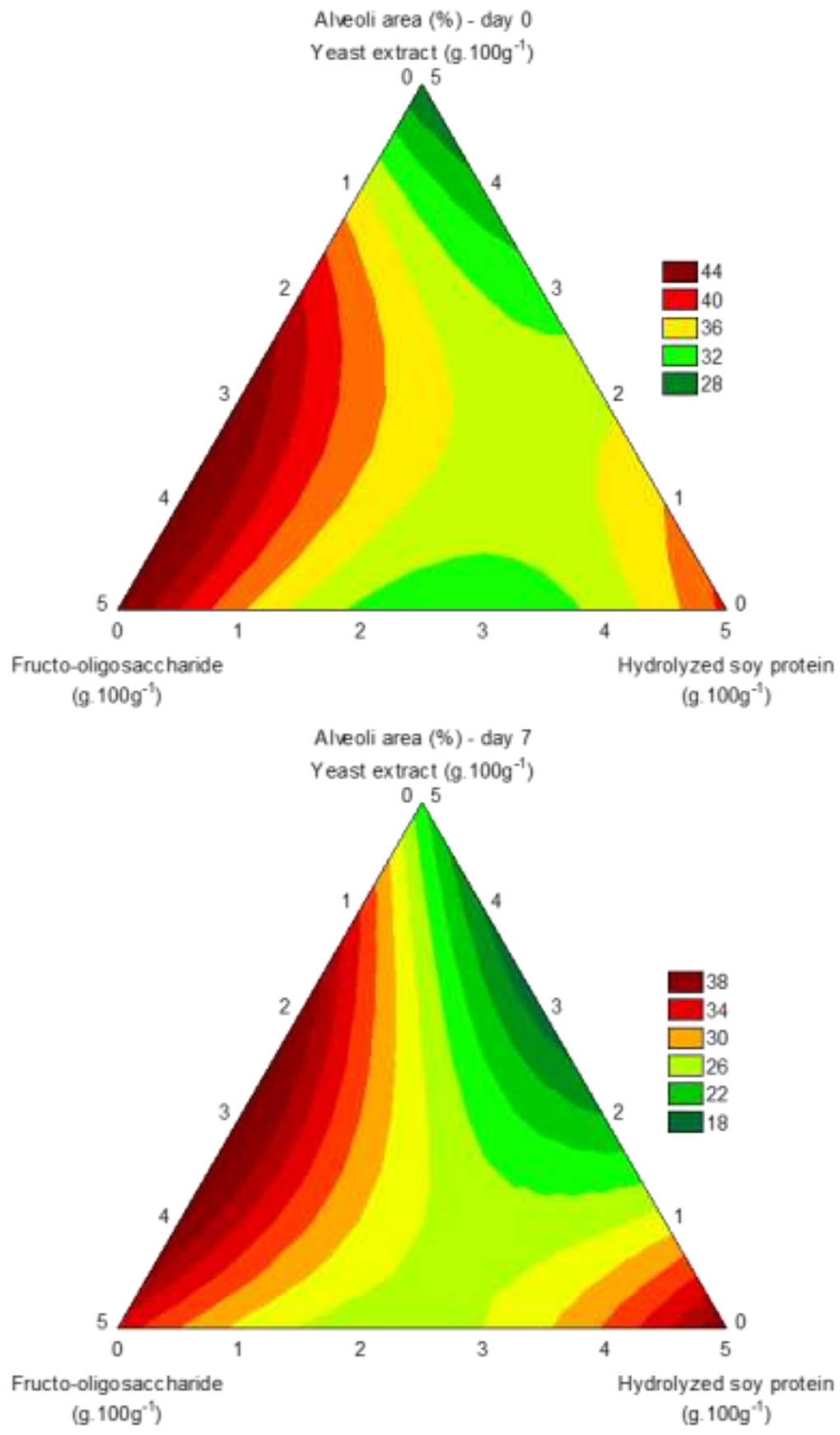

Source: Authors (2021). 
Table 6 - Mathematical models for the dependent variables for dough and bread properties in codified levels with statistical significance $(P<0.10)$.

\begin{tabular}{llll}
\hline Dependent variable & Day & Mathematical model & $\mathbf{R}^{2}$ \\
\hline Proofing time (min) & 7 & $45.50 \mathrm{x}_{1}+65.77 \mathrm{x}_{2}+36.23 \mathrm{x}_{3}-41.46 \mathrm{x}_{1} \mathrm{x}_{2}+59.46 \mathrm{x}_{1} \mathrm{x}_{3}-198.00 \mathrm{x}_{1} \mathrm{x}_{2} \mathrm{x}_{3}$ & 0.9300 \\
Dough volume increase (AUC) & 0 & $2840 \mathrm{x}_{1}+2844 \mathrm{x}_{2}+2256 \mathrm{x}_{3}+3977 \mathrm{x}_{1} \mathrm{x}_{2}+3068 \mathrm{x}_{1} \mathrm{x}_{3}-22897 \mathrm{x}_{1} \mathrm{x}_{2} \mathrm{x}_{3}$ & 0.8729 \\
& 7 & $8934 \mathrm{x}_{1}+5324 \mathrm{x}_{2}+6204 \mathrm{x}_{3}-7567 \mathrm{x}_{1} \mathrm{x}_{2}-2518 \mathrm{x}_{1} \mathrm{x}_{3}+55480 \mathrm{x}_{1} \mathrm{x}_{2} \mathrm{x}_{3}$ & 0.9865 \\
Specific volume $\left(\mathrm{L.kg}{ }^{-1}\right)$ & 0 & $3.12 \mathrm{x}_{1}+1.89 \mathrm{x}_{2}+1.34 \mathrm{x}_{3}+2.15 \mathrm{x}_{1} \mathrm{x}_{2}+3.68 \mathrm{x}_{1} \mathrm{x}_{3}-10.30 \mathrm{x}_{1} \mathrm{x}_{2} \mathrm{x}_{3}$ & 0.9393 \\
& 7 & $3.08 \mathrm{x}_{1}+1.68 \mathrm{x}_{2}+2.80 \mathrm{x}_{3}+3.48 \mathrm{x}_{1} \mathrm{x}_{2}-2.62 \mathrm{x}_{1} \mathrm{x}_{3}-20.76 \mathrm{x}_{1} \mathrm{x}_{2} \mathrm{x}_{3}$ & 0.9008 \\
Firmness (N) & 0 & $12.76 \mathrm{x}_{1}+14.57 \mathrm{x}_{2}+15.03 \mathrm{x}_{3}-7.58 \mathrm{x}_{1} \mathrm{x}_{2}-13.47 \mathrm{x}_{1} \mathrm{x}_{3}+72.04 \mathrm{x}_{1} \mathrm{x}_{2} \mathrm{x}_{3}$ & 0.8669 \\
& 7 & $20.24 \mathrm{x}_{1}+24.14 \mathrm{x}_{2}+22.28 \mathrm{x}_{3}-32.21 \mathrm{x}_{1} \mathrm{x}_{2}-41.89 \mathrm{x}_{1} \mathrm{x}_{3}+132.02 \mathrm{x}_{1} \mathrm{x}_{2} \mathrm{x}_{3}$ & 0.9070 \\
Alveoli average size $\left(\mathrm{mm}^{2}\right)$ & 0 & $45.00 \mathrm{x}_{1}+80.06 \mathrm{x}_{2}+35.58 \mathrm{x}_{3}-95.18 \mathrm{x}_{1} \mathrm{x}_{2}+128.81 \mathrm{x}_{1} \mathrm{x}_{3}-79.76 \mathrm{x}_{2} \mathrm{x}_{3}$ & 0.8421 \\
& 7 & $19.45 \mathrm{x}_{1}+12.03 \mathrm{x}_{2}+15.16 \mathrm{x}_{3}+36.66 \mathrm{x}_{1} \mathrm{x}_{2}+47.76 \mathrm{x}_{1} \mathrm{x}_{3}-255.97 \mathrm{x}_{1} \mathrm{x}_{2} \mathrm{x}_{3}$ & 0.8924 \\
Alveoli area (\%) & 0 & $44.72 \mathrm{x}_{1}+38.63 \mathrm{x}_{2}+25.95 \mathrm{x}_{3}-44.57 \mathrm{x}_{1} \mathrm{x}_{2}+28.52 \mathrm{x}_{1} \mathrm{x}_{3}$ & 0.8758 \\
& 7 & $33.32 \mathrm{x}_{1}+37.87 \mathrm{x}_{2}+22.59 \mathrm{x}_{3}-41.90 \mathrm{x}_{1} \mathrm{x}_{2}+45.42 \mathrm{x}_{1} \mathrm{x}_{3}-4869 \mathrm{x}_{2} \mathrm{x}_{3}$ & 0.8901 \\
\hline
\end{tabular}

$\mathrm{x}_{1}=$ fructo-oligosaccharides; $\mathrm{x}_{2}=$ hydrolyzed soy protein; $\mathrm{x}_{3}=$ yeast extract; AUC $=$ area under curve. Source: Authors (2021).

\subsection{Numerical optimization and mathematical models' validation.}

To determine the optimal point of the formulation, all cryoprotectants were kept in range, and the responses were evaluated to obtain the best results. The dependent variables statistically significant $\left(P<0.10 ; \mathrm{F}_{\text {cal }} / \mathrm{F}_{\text {tab }}>1\right.$ and $\left.\mathrm{R}^{2}>0.80\right)$ were defined at maximum importance (ranged from 1 to 5 , where 1 is considered the less and 5 the most important) and the goal was defined as "minimize" for proofing time, firmness and alveoli average size and "maximize" for dough volume increase, specific volume, and alveoli area (Table 7).

The best solution was obtained with the use of $3.45 \%$ fructo-oligosaccharides and $1.55 \%$ hydrolyzed soy protein, without the addition of yeast extract. This formulation was processed in true triplicate and the dependent variables were analyzed to verify the validity of the mathematical models. Under the conditions stipulated, a degree of desirability of $79.60 \%$ was established. In general, it was observed that mathematical models could predict experimental values and were validated since the relative deviation found was up to $\pm 10 \%$. 
Table 7 - Results for experimental and predictive values and relative deviation regarding the validation of mathematical models.

\begin{tabular}{|c|c|c|c|c|c|c|}
\hline \multirow{2}{*}{\multicolumn{2}{|c|}{ Parameters }} & \multirow{2}{*}{ Goal } & \multirow{2}{*}{ Importance } & \multicolumn{3}{|l|}{ Solution } \\
\hline & & & & \multicolumn{2}{|c|}{ Coded value } & Real value \\
\hline \multicolumn{7}{|l|}{ Independent variables } \\
\hline \multicolumn{2}{|l|}{ Fructo-oligosaccharides } & In range & 3 & 0.69 & & $3.45 \%$ \\
\hline \multicolumn{2}{|l|}{ Hydrolyzed soy protein } & In range & 3 & 0.31 & & $1.55 \%$ \\
\hline \multicolumn{2}{|l|}{ Yeast extract } & In range & 3 & 0.00 & & $0.00 \%$ \\
\hline \multicolumn{2}{|l|}{ Parameter } & Goal & Importance & Solution & $\begin{array}{l}\text { Optimal point } \\
\text { values }\end{array}$ & $\begin{array}{l}\text { Relative } \\
\text { deviation }\end{array}$ \\
\hline \multicolumn{7}{|l|}{ Dependent variables } \\
\hline Proofing time (min) & Day 7 & Minimize & 5 & 42.87 & $47.53 \pm 2.56$ & $9.80 \%$ \\
\hline \multirow{2}{*}{$\begin{array}{l}\text { Dough volume } \\
\text { increase (AUC) }\end{array}$} & Day 0 & \multirow{2}{*}{ Maximize } & 5 & 3692 & $3485 \pm 174$ & $-5.94 \%$ \\
\hline & Day 7 & & 5 & 6196 & $6350 \pm 151$ & $2.42 \%$ \\
\hline Specific volume & Day 0 & \multirow{2}{*}{ Maximize } & 5 & 3.32 & $3.25 \pm 0.68$ & $2.15 \%$ \\
\hline $\mathrm{L} . k g^{-1}$ & Day 7 & & 5 & 3.40 & $3.56 \pm 0.52$ & $4.49 \%$ \\
\hline \multirow{2}{*}{ Firmness (N) } & Day 0 & \multirow{2}{*}{ Minimize } & 5 & 11.70 & $12.75 \pm 1.14$ & $8.24 \%$ \\
\hline & Day 7 & & 5 & 14.56 & $14.12 \pm 2.56$ & $-3.12 \%$ \\
\hline \multirow{2}{*}{$\begin{array}{l}\text { Alveoli average size } \\
\left(\mathrm{mm}^{2}\right)\end{array}$} & Day 0 & \multirow{2}{*}{ Minimize } & 5 & 35.51 & $38.96 \pm 3.85$ & $8.86 \%$ \\
\hline & Day 7 & & 5 & 24.99 & $27.02 \pm 3.98$ & $7.51 \%$ \\
\hline \multirow{2}{*}{ Alveoli area $(\%)$} & Day 0 & \multirow{2}{*}{ Maximize } & 5 & 33.30 & $32.50 \pm 4.21$ & $-2.46 \%$ \\
\hline & Day 7 & & 5 & 25.77 & $28.32 \pm 2.43$ & $9.00 \%$ \\
\hline Desirability & 0.7960 & & & & & \\
\hline
\end{tabular}

AUC $=$ area under curve. Source: Authors (2021).

\section{Conclusion}

The demand for products for individuals with disorders associated with gluten consumption is increasing. To serve this niche market, the frozen dough has been growing and has gained notoriety in the breadmaking industry. However, for the development of gluten-free frozen dough, it is still necessary to improve the technologies applied in the formulation and the processing steps. Thus, cryopreservation appears as a highly viable alternative in the development of frozen doughs for glutenfree bread, providing a solution concerning the viability of yeast cells, which is one of the great challenges in obtaining glutenfree frozen dough.

This study highlights the application and performance evaluation of the fructo-oligosaccharides, hydrolyzed soy protein and yeast extract as natural cryoprotectants and demonstrates a promising effect, where the production of the optimal point of this gluten-free bread through an experimental design was allowed with the combination of $69 \%$ of fructo-oligosaccharides and $31 \%$ hydrolyzed soy protein, without the use of yeast extract, considering a total of $6 \%$ application of cryoprotectants in a combined way over the total amount of rice flour used in the formulation. The technological characteristics analyzed through Surface Response Methodology resulted in gluten-free bread production with a higher specific volume and less crumb firmness, consequently softer and with possible acceptance by the consumers. We believe that the development of emerging technologies (unconventional methods) to reduce the time and costs in the baking stage (microwave, infrared) and the commercialization of 
individual servings (portions), resulting in technological innovations and the development of new products for gluten-free breadmaking.

\section{Acknowledgments}

The authors would like to thank the Federal University of Jequitinhonha and Mucuri Valleys (UFVJM) and the Institute of Science and Technology (ICT) for the institutional support. To the Coordination for the Improvement of Higher Education Personnel (CAPES) for granting the scholarship to D. O. Teotônio and financial support (funding code 001). To the Research Support Foundation of the State of Minas Gerais (FAPEMIG) for granting the scholarship to P. T. G. Gomes and M. P. Silveira. We also are grateful to the National Council for Scientific and Technological Development (CNPq) for financial support (Universal project, protocol 424938/2016-2) and for granting the scholarship to B. A. F. da Costa.

\section{References}

AACCI. (2010). American Association of Cereal Chemists International. Approved Methods of American Association of Cereal Chemists. AACC, St. Paul.

Arslain, K., Gustafson, C. R., Baishya, P., \& Rose, D. J. (2021). Determinants of gluten-free diet adoption among individuals without celiac disease or nonceliac gluten sensitivity. Appetite, 156, 104958, 1-8. https://doi.org/10.1016/j.appet.2020.104958.

Bender, D., \& Schönlechner, R. (2020). Innovative approaches towards improved gluten-free bread properties. Jounal of Cereal Science, 91, 102904,1-8 . https://doi.org/10.1016/j.jcs.2019.102904.

Bhattacharya, S. (2018). Cryoprotectants and their usage in cryopreservation process. In: Bozkurt, Y. (Ed.). Biomedical and Biological Sciences, IntechOpen.

Brasil. (2003). Ministério da Saúde. Agência Nacional de Vigilância Sanitária. Lei $\mathrm{n}^{\circ}$ 10.674, de 16 de maio de 2003. Obriga que os produtos alimentícios comercializados informem sobre a presença de glúten, como medida preventiva e de controle da doença celíaca. Diário Oficial da União, Poder Executivo, Brasília, DF, 19 de maio de 2003.

Brites, L. T. G. F., \& Schmiele, M., Steel, C. J. (2018). Gluten-Free bakery and pasta products. In: Holban, A. M., Grumezescu, A. M. (Eds.). Alternative and replacement foods. Academic Press.

Cabanillas, B. (2019). Gluten-related disorders: Celiac disease, wheat allergy, and nonceliac gluten sensitivity. Critical Reviews in Food Science and Nutrition, $60,2606-2621$.

Catassi, G. N., Naspi, L., \& Catassi, C. (2021). Non-Celiac Gluten Sensitivity. In: Weiss, G. A. (Ed.). Diagnosis and Management of Gluten-Associated Disorders. Springer.

Chen, G., Jansson, H., Lustrup, K. F., \& Swenson, J. (2012). Formation and distribution of ice upon freezing of different formulations of wheat bread. Journal of Cereal Science, 55, 279-284.

Chen, X., Wu, J-H., Li, L., \& Wang, S-Y. (2017). The cryoprotective effects of antifreeze peptides from pigskin collagen on texture properties and water mobility of frozen dough subjected to freeze-thaw cycles. European Food Research Technology, 243, 1149-1156.

Čukelj, N., \& Novotni, D. (2018). Freezing of bread. In: Ferranti, P, Berry, E. M., \& Jock, A. R. (Eds.). Encyclopedia of Food Security and Sustainability, Elsevier.

Derringer, G., Suich, R. (1980). Simultaneous optimization of several response variables. Journal of Quality Technology, 12, 214-219. https://doi.org/10.1080/00224065.1980.11980968.

Ding, X., Zhang, H., Wang, L., Qian, H., Qi, X., \& Xiao, J. (2015). Effect of barley antifreeze protein on thermal properties and water state of dough during freezing and freeze-thaw cycles. Food Hydrocolloids, 47, 32-40. https://doi.org/10.1016/j.foodhyd.2014.12.025.

Fellows, P. J. (2016). Food processing technology: principles and practice. Woodhead Publishing, 1152p.

Franco, A. W., \& Silva, A. F. (2016). Pão sem glúten: Busca por novos produtos. Revista Processos Químicos, 20, 173-190. [Gluten free bread: Search for new products. Chemical Processes Magazine, 20, 173-190. https://doi.org/10.19142/rpq.v10i20.363.

Halagarda, M. (2017). Effects of trehalose and dough additives incorporating enzymes on physical characteristics and sensory properties of frozen savory Danish dough. LWT - Food Science and Technology, 86, 603-610. https://doi.org/10.1016/j.1wt.2017.08.048.

He, Y., Guo, J., Ren, G., Cui, G., Han, S., \& Liu, J. (2020). Effects of Konjac glucomannan on the water distribution of frozen dough and corresponding steamed bread quality. Food Chemistry, 330, 1-7, 127243. https://doi.org/10.1016/j.foodchem.2020.127243.

James, C., Purnell, G., \& James, J. S. (2015). A review of novel and innovative food freezing technologies. Food and Bioprocess Technology, 16, 1616-1634. Retrieved from https://link.springer.com/article/10.1007/s11947-015-1542-8.

Kenijz, V. N., Nesterenko, A. A., \& Zayats, M. S. (2019). Cryoprotectants in the technology for the production of frozen bakery products. Food Technology, 4, 23-29. 
Kringel, H. D., Filipini, G. S., \& Salas-Mellado, M. M. (2017). Influence of phosphorylated rice flour on the quality of gluten-free bread. Internacional Journal of Food Science and Technology, 52, 1291-1298. https://doi.org/10.1111/ijfs.13376.

Kunsler, N. L. F. (2017). Estudo da impregnação a vácuo de trealose como crioprotetor em morangos. Dissertação. Universidade Federal do Rio Grande do Sul. Porto Alegre, 2017.

Leonardi, J. G., \& Azevedo, B. M. (2018). Métodos de conservação de alimentos. Revista Saúde em Foco, $10,51-61$.

Macedo, L. L., Vimercati, W. C., \& Araújo, S. C. (2020). Fructo-oligosaccharides: nutricional, technological and sensory aspects. Brazilian Journal of Food Technology, 23, 1-9, e2019080. http://dx.doi.org/10.1590/1981-6723.08019.

Maity, T., Saxena, A., Raju, P. S. (2017). Use of hydrocolloids as cryoprotectant for frozen foods. Critical Review in Food Science and Nutrition, 58, 420-435. Meziani, S., Jasniewski, J., Gaiania, C., Ioannou, I., Muller, J-M., Ghoul, M., Desobry, S. (2011). Effects of freezing treatments on viscoelastic and structural behavior of frozen sweet dough. Journal of Food Engineering, 107, 358-365. https://doi.org/10.1016/j.jfoodeng.2011.07.003.

Meziani, S., Kaci, M., Jacquot, M., Jasniewski, J., Ribotta, P., Muller, J-M., Ghoul, M., \& Desobry, S. (2012). Effect of freezing treatments and yeast amount on sensory and physical properties of sweet bakery products. Journal of Food Engineering, 111, 336-342. https://doi.org/10.1016/j.jfoodeng.2012.02.015.

Motta, J. P. R., Paraguassú-Braga, F. H., Bouzas, L. F., \& Porto, L. C. (2014). Evaluation of intracellular and extracellular trehalose as a cryoprotectant of stem cells obtained from umbilical cord blood. Cryobiology, 68, 343-348. https://doi.org/10.1016/j.cryobiol.2014.04.007.

Neves, N. A., Gomes, P. T. G., Carmo, E. M. R., Silva, B. S., \& Amaral, T. N. Schmiele, M. (2020). Sourdough and jaboticaba (Plinia cauliflora) for improvement on pan bread characteristics. Research, Society and Development, 9, e90691110552.

Neves, N. A., Gomes, P. T. G., \& Schmiele, M. (2020). An exploratory study about the preparation and evaluation of sourdough breads with araticum pulp (Annona crassiflora Mart.) Research, Society and Development, 9, e956998036.

Nunes, M. H. M. P., Aquino, L. A., Santos, L. P. D., Xavier, F. O., Dezordi, L. R., \& Assunção, N. S. (2015). Yield of the irrigated wheat crop subjected to nitrogen application and to inoculation with Azospirillum brasilense. Brazilian Journal of Soil Science, 39, 174-182. http://dx.doi.org/10.1590/01000683rbcs20150354.

Ortolan, F., Brites, L. T. G., Montenegro, F. M., Schmiele, M., Steel, C. J., Clerici, M. T. P. S., Almeida, E. L., \& Chang, Y. K. (2015). Effect of extruded wheat flour and gelatinized cassava starch on process and quality parameters of french-type bread elaborated from frozen dough. Food Research International, 76, 402-409. DOI: 10.1016 / j.foodres.2015.07.010.

Pacckia-Doss, P. P., Chevallier, S., Pare, A., \& Le-Bail, A. (2019). Effect of supplementation of wheat bran on dough aeration and final bread volume. Journal of Food Engineering, 252, 28-35. https://doi.org/10.1016/j.jfoodeng.2019.01.014.

Park, E. Y., Jang, S-B., \& Lim, S-T. (2016). Effect of fructo-oligosaccharide and isomalto-oligosaccharide addition on baking quality of frozen dough. Food Chemistry, 213, 157-162. 10.1016/j.foodchem.2016.06.067.

Pereira, A. S., Shitsuka, D. M., Pereira, F. J., \& Shitsuka, R. (2018). Metodologia da pesquisa científica. UFSM. https://repositorio.ufsm.br/bitstream/handle/1 /15824/Lic_Computacao_Metodologia-Pesquisa-Cientifica.pdf?sequence=1.

Rinaldi, M., Paciulli, M., Caligiani, A., Scazzina, F., \& Chiavaro, E. (2017). Sourdough fermentation and chestnut flour in gluten-free bread: A shelf-life evaluation. Food Chemistry, 224, 144-152. https://doi.org/10.1016/j.foodchem.2016.12.055.

Rodrigues, M. I., \& Iemma, A. F. (2014). Experimental design and process optimization. CRC Press, 336p.

Romano, A., Toraldo, G., Cavella, S., \& Masi, P. (2007). Description of leavening of bread dough with mathematical modelling. Journal of Food Engineering, 83, 142-148. https://doi.org/10.1016/j.jfoodeng.2007.02.014.

Rosa, S. P. L., \& Cruz, J. D. (2017). Applicability of fruto-oligosaccharides as functional food. Revista de Nutrição e Vigilância em Saúde, [Journal of Nutrition and Health Surveillance], 4, 68-74.

Rosell, C. M., \& Gómez, M. (2007). Freezing in breadmaking performance: frozen dough and parbaked bread. Food Reviews International, 23, 303-319. DOI: $10.1080 / 87559120701418368$.

Roszkowska, A. Pawlick, M., Mroczek, A., Balabuszek, K., \& Neradko-Iwanicka, B. (2019). Non-celiac gluten sensitivity: a review. Medicina, 55 , 222.

Scherf, K. A. (2019). Immunoreactive cereal proteins in wheat allergy, non-celiac gluten/wheat sensitivity (NCGS) and celiac disease. Current Opinion in Food Science, 25, 35-41. https://doi.org/10.1016/j.cofs.2019.02.003.

Schmiele, M., Felisberto, M. H. F., Clerici, M. T. P. S. C., \& Chang, Y. K. (2017). Mixolab ${ }^{\text {TM }}$ for rheological evaluation of wheat flour partially replaced by soy protein hydrolysate and fructooligosaccharides for bread production. LWT - Food Science and Technology, 76, 259-269. https://doi.org/10.1016/j.lwt.2016.07.014

Schmiele, M., Sampaio, U. M., \& Clerici, M. T. P. S. (2019). Basic principles: Composition and properties of starch. In: Clerici, M. T. P. S. \& Schmiele, M. (Eds.). Starches for food application: chemical, technological and health properties. Elsevier. https://doi.org/10.1016/B978-0-12-809440-2.00001-0.

Silveira, M. P., Cardoso, G. P., \& Schmiele, M. (2019). Estimativa de um padrão de identidade e qualidade de pães de forma comerciais. In: IV JEA - Jornada Regional Sudeste de Engenharia de Alimentos, Diamantina.

Sola, M. C., Oliveira, A. P., Feistel, J. C., \& Rezende, C. S. M. (2012). Manutenção de microrganismos: conservação e viabilidade. Enciclopédia Biosfera, 8, 1398-1418. 
Research, Society and Development, v. 10, n. 3, e44510313556, 2021

(CC BY 4.0) | ISSN 2525-3409 | DOI: http://dx.doi.org/10.33448/rsd-v10i3.13556

Souza, N. C. O., Oliveira, L. L., Alencar, E. R., Moreira, G. P., Leandro, E. S., Ginani, V. C., \& Zandonadi, R. P. (2018). Textural, physical, and sensory impacts of the use of green banana puree to replace fat in reduced sugar pound cakes. LWT - Food Science and Technology, 89, 617-623, https://doi.org/10.1016/j.1wt.2017.11.050.

Srinivasan, D., \& Parkin, K. L. (2017). Fennema ’s Food Chemistry. CRC Press, Boca Raton, 1123p.

Tasiguano, B. L., Villarreal, C., Schmiele, M., \& Vernaza, M. G. (2019). Effect of cooking time of pumpkin (Cucurbita maxima) and the addition of glucose oxidase on the increase of resistant starch in loaf bread. Información Tecnológica, 30, 167-178. http://dx.doi.org/10.4067/S0718-07642019000300167.

Tonetto, C. T. (2018). Melhoria nas características sensoriais de pão isento de glúten a partir da fermentação natural. Dissertação. Universidade Federal de Santa Maria.

Wang, X., Pei, D., Teng, Y., \& Liang, J. (2018). Effects of enzymes to improve sensory quality of frozen dough bread and analysis on its mechanism. Journal of Food Science and Technology, 55, 389-39810.1007 / s13197-017-2950-8.

Wong, S. W. D. (2018). Mechanism and theory in food chemistry. Springer, 450p.

Xavier-Santos, D., Bedani, R., Perego, P., Converti, A., \& Saad, S. M. I. (2019). L. acidophilus La-5, fructo-oligosaccharides and inulin may improve sensory acceptance and texture profile of a synbiotic diet mousse. LWT - Food Science and Technology, 105, 329-335. 